\title{
Proposed Method for Cost Assessment of Seismic Mitigation Designs for Reinforced Concrete Buildings According to ECP Code
}

\author{
Yasser Fayed1, Mohamed E. Sobaih², Yasser El Hakem³ \\ ${ }^{1}$ Civil Engineering Department, Giza engineering Institute GEI, Giza, Egypt \\ ${ }^{2}$ Civil Engineering Department, Faculty of Engineering, Cairo University, Giza, Egypt \\ ${ }^{3}$ Construction Research Institute, National Water Research Center, Cairo, Egypt \\ Email: yasser.fayed3011@gmail.com, yasser.fayed@gei.edu.eg, msobaih2@yahoo.com, yelhakem@yahoo.com
}

How to cite this paper: Fayed, Y., Sobaih, M.E. and El Hakem, Y. (2019) Proposed Method for Cost Assessment of Seismic Mitigation Designs for Reinforced Concrete Buildings According to ECP Code. Open Journal of Civil Engineering, 9, 319-355. https://doi.org/10.4236/ojce.2019.94023

Received: July 10, 2019

Accepted: December 17, 2019

Published: December 20, 2019

Copyright (c) 2019 by author(s) and Scientific Research Publishing Inc. This work is licensed under the Creative Commons Attribution International License (CC BY 4.0).

http://creativecommons.org/licenses/by/4.0/

\begin{abstract}
The Earthquake can be considered as a natural phenomenon or a disaster based on the seismic response of structures during a severe earthquake that plays a vital role in the extent of structural damage and resulting injuries and losses. It is necessary to predict the performance of the existing structures and structures at the design stage when it subjected to an earthquake load. Also, it is needed to predict the repair cost required for the rehabilitation of the existing buildings that is insufficient in seismic resistance, and the construction cost and the expected repairing cost for the structures at the design stage that designed to have a ductile behavior with acceptable cracks. This study aims to propose a method for seismic performance evaluation for existing and new structures depending on the width of cracks resulted from the seismic exposure. Also, it assesses the effect of building performance during earthquakes on its life cycle cost. FEMA 356 criteria were used to predict the building responses due to seismic hazard. A case study of seven-story reinforced concrete building designed by four design approaches and then analyzed by static nonlinear pushover analysis to predict its response and performance during earthquake events using Sap 2000 software. The first design approach is to design the building to resist gravity loads only by using ECP code. The second one is to design the building to resist gravity loads and seismic loads by using static linear analysis according to ECP code. The third one is to design the building to resist gravity loads and seismic loads by using static linear analysis according to the regulations of the Egyptian Society of Earthquake Engineering (ESEE). Finally the fourth one is to design the building as the second approach but with ground acceleration greater by five times than it or by using ductility factor $\mathrm{R}=1$. The methodology followed in this study provides initial
\end{abstract}


guidelines, and steps required to assess the seismic performance and the cost associated with using a variety of design methods for reinforced concrete structures resisting earthquakes, selecting the retrofitting strategies that would be indicated to repair the structure after an earthquake.

\section{Keywords}

Performance Based Analysis, Pushover Analysis, Cost Assessment, Crack Width

\section{Introduction}

The last earthquake events in various world areas and the resulting harms, especially human fatalities, have shown that the structures cannot withstand the earthquake loads. The large damages caused by the earthquake happened in Cairo in 1992 showed that at the construction time, the structures were designed to sustain only vertical loads and had ineffective horizontal load resistance. That expresses that, there are low ductility elements, shear resistance, and steel confinement in the plastic hinge zone that was founded in columns and beam column connections. So it is urgent to assess the seismic performance of existing structures and to constantly refresh the seismic codes for the design of the new structures.

The design of structures for seismic load resistance forced in the Egyptian design codes that motivated the Ministry of Housing and Buildings to regularly update the Egyptian codes provisions to consider the earthquake loads effect. After October 1992, a set of Egyptian codes has been released to avoid building failure and to control significant damages in structural elements. Earthquake analysis has many considerations that have been formed using the performance assessment of existing structures that have been subjected to a severe earthquake. To get a well-engineered structure, it must satisfy the seismic performance requirements that include the careful attention in analysis, design, reinforcement detailing, and good construction. The successful integration of analysis, design, and construction achieves the safety of the structure.

Krawinkler et al. [1], used the pushover analysis method to assess the building performance to get the inter-story drifts that take into account the changes in stiffness and strength, that can be used for the evaluation of P- $\Delta$ effect, determinate the effect of strength deterioration of elements on the behavior of the whole structure, get the sequence of failure of structure members and identify the weakness points in the structural members.

Maske [2], uses the nonlinear static pushover analysis, which is considered a common method for assessment of seismic performance for the new and existing structures. To discriminate the weakness zones in the building and then choose if it can be retrofitted or rehabilitated according to its level of damage. 
He performed the pushover analysis on multistoried frame structures by using SAP2000 software. He analyzed two framed structures with 5 and 12 floors, respectively. The results concluded from his study display that the behavior of properly reinforcement detailed reinforced concrete frame building is adequate as concluded by the capacity curve with demand curve intersection and the plastic hinges distribution in the structural members.

To perform the performance-based design, one must develop the evaluation method of the seismic resistant performance for the reinforced concrete structural members. The performance limit states are classified into three limit states, serviceability limit state, safety limit states, and damage control limit states. Each state is defined by the damages of the structural members. The yielding of reinforcing steel bars and the width of crack are used as the index of the damages. As the result of the plastic nonlinear frame analysis based on the performance-based design process method, the crack width of each member is calculated at each step [3].

Igarashi [4], developed an approach for assessment of seismic damage in reinforced concrete members which is important for exact selection of the most suitable repairing technique for structures damaged and affected by earthquakes risk. He presents the concepts and outlines of damage assessment steps of ductile reinforced concrete structural members. The suggested analytical models assess the width of crack, the length of crack, and the area of concrete that spalled in ductile column and beam. These models are planned to be applied to pushover analysis of framed structure in practical seismic design.

\section{Equivalent Static Method According to ECP (2012)}

In the preliminary design process, equivalent linear static seismic analysis is used to get the design straining actions in structural members, and then get the strength demands for the designed structural member. One can get the equivalent static seismic forces by calculating the elastic design spectrum acceleration divided by a reduction factor that depends on the structural system that named as the ductility amount response factor $(R)$.

In accordance with (ECP-201-2012) [5] code, the base shear force $\left(F_{b}\right)$ resulted from the analysis of each horizontal direction of the structure to seismic loads is computed with the shown formula:

$$
F_{b}=\gamma \times S_{d}\left(T_{1}\right) \times \lambda \times W / g
$$

where, $S_{d}\left(T_{1}\right)$ is the design response spectrum ordinate at time period $T_{1} . T_{1}$ is the vibration time period of the structure in the direction of the horizontal load analyzed. $W$ is the weight magnitude of the structure considering its total elements. $g$ is the ground acceleration. $\gamma$ is an important factor for the building and its value depends on the building function. $\lambda$ is the modal mass correction factor. $n:$ is the number of floors that formed the structure.

The value of the vibration time period in seconds $\left(T_{1}\right)$ is computed using the 
shown formula:

$$
T_{1}=C_{t} \times H^{3 / 4}
$$

where, $C_{t}$ is a parameter depends on the structural system of the building and the material of the structure and $C_{t}=0.075$ for a concrete framed structure and $\mathrm{H}$ is the total height of the building in $\mathrm{m}$, from the level of footing or from the top of a rigid story.

The design response spectrum ordinate $S_{d}\left(T_{1}\right)$, can be computed by the shown formula:

$$
S_{d}\left(T_{1}\right)=\left[\frac{2.5}{R}\right] \times a_{g} \times \gamma \times S \times \eta\left[\frac{T_{c}}{T_{1}}\right] \geq 0.2 \times a_{g} \times \gamma
$$

where, $a_{g}$ is the equivalent design ground acceleration for the ground motion of the earthquake for a specific return period. $T_{c}$ is the peak value of the constant spectral time period acceleration. $H$ is a damping parameter of the horizontal elastic response spectrum, where $\eta=1$ corresponds to a normal ratio of $5 \%$ viscous damping (in the case of reinforced concrete structures). $S$ is the parameter depends on the soil type. $\gamma$ is the important factor for the building depends on the building function. $R$ is a reduction factor depends on the structural system of the structure used to resist seismic loads, it represents the ductility amount of the structure.

The Arab Republic of Egypt is divided into five seismic zones according to the ECP code (ECP-201-2012) [5] based on the design ground acceleration as shown in Table 1, and Figure 1.

The lateral forces $F_{i}$ on each story with mass $m_{i}$ shall be computed as follows:

$$
F_{i}=\left[\frac{h_{i} \times W_{i}}{\sum_{j=1}^{n} h_{j} \times W_{j}}\right] \times F_{b}
$$

where, $F_{i}$ is the earthquake force acting horizontally on story $i . F_{b}$ is the total base shear force due to earthquake (Equation (1)). $h_{i}$ and $h_{j}$ are the heights of each story with masses $m_{i}$ and $m_{j}$ above the foundation level, respectively. $W_{i}$ and $W_{j}$ are the weights of masses $m_{i}$ and $m_{j}$, respectively. $n$ is the number of floors above the foundation level.

Equation (4) computes the seismic force on each floor depending only on the story height.

Table 1. Seismic zones and related design ground acceleration (ECP-201-2012) [5].

\begin{tabular}{cc}
\hline Zone & Design Ground Acceleration \\
\hline 1 & $0.10 \mathrm{~g}$ \\
2 & $0.125 \mathrm{~g}$ \\
3 & $0.15 \mathrm{~g}$ \\
4 & $0.20 \mathrm{~g}$ \\
$5-\mathrm{a}$ & $0.25 \mathrm{~g}$ \\
$5-\mathrm{b}$ & $0.30 \mathrm{~g}$ \\
\hline
\end{tabular}




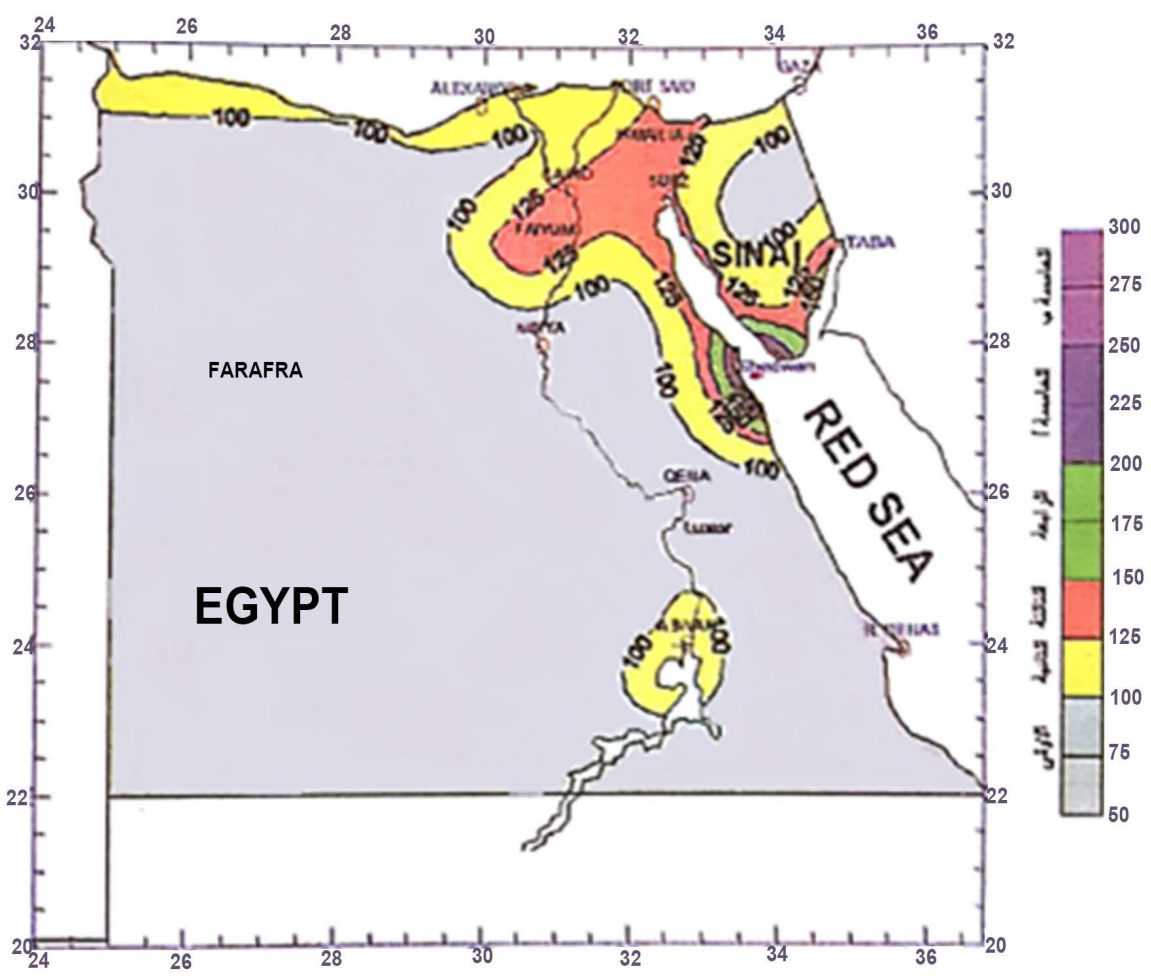

Figure 1. Seismic zone regions of Egypt (ECP-201-2012) [5].

\section{Equivalent Static Method According to the Egyptian Society for Earthquake Engineering (ESEE)}

The Egyptian Society for Earthquake Engineering (ESEE 1988) [6] has developed regulations for the design of structures to withstand and release earthquake loads. The design criteria in this case are based on working limit state design approach. The lateral earthquake forces calculated shall be applied together at each floor and roof level.

The total base horizontal earthquake load:

Each structure shall be designed and constructed to confront and release a total horizontal earthquake load $(V)$ in each building direction under consideration which computed by the shown formula:

$$
V=C_{s} \times W_{t}
$$

where, $C_{s}$ is the seismic design coefficient and $W_{t}$ is the total weight of the building considering dead loads and live loads.

The horizontal acceleration coefficient can be calculated using the equation mentioned below:

$$
C_{s}=Z \times I \times S \times M \times R \times Q
$$

where, $C_{s}$ is a coefficient of Seismic design and $Z$ is the factor of seismic zoning determined from the shown formula:

$$
Z=A \times C \times F
$$

where, $A$ is the horizontal earthquake ground acceleration detected according to 
the building location on the seismic zoning map. $C$ is the standardized response spectrum coefficient for average damping of $5 \% . F$ is the foundation soil factor. $I$ is the important factor of the building. $S$ is the factor depends on the type of the structural system, the value of $(S)$ shall be determined separately for each direction of the building. $M$ is the factor that depends on the construction material. $\mathrm{R}$ is the risk factor expresses the amount of risk exposure. $Q$ is a factor that shows the quality of materials used and the quality of construction.

\section{Pushover Analysis}

Pushover analysis is a method in which a series of incremental static horizontal load applied on the structure to get the load-displacement capacity curve of the building. This load still increasing until the structure reaches its maximum displacement (Hakim 2014) [7]. A pushover analysis results and strategy are presented in Figure 2, Figure 3.
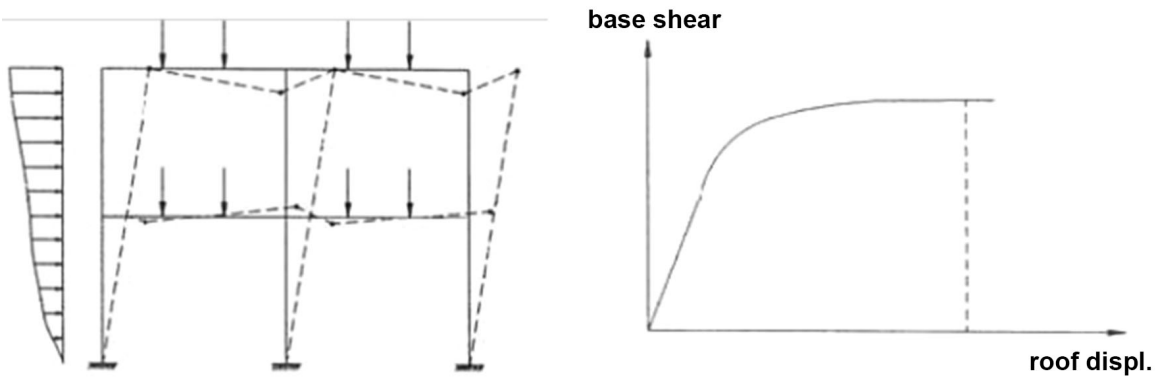

Figure 2. Illustration of pushover analysis (Hakim 2014) [7].

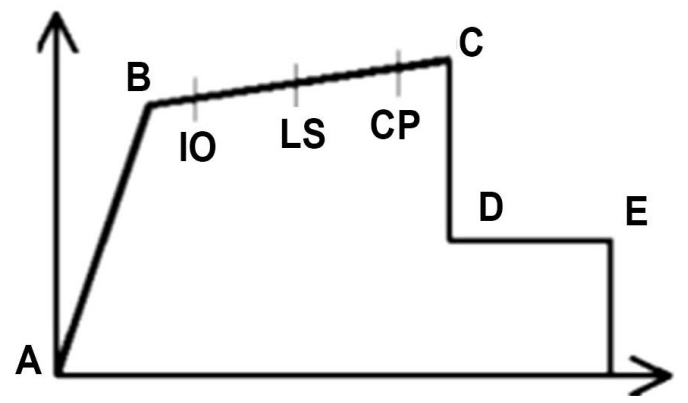

Figure 3. Typical Load-deformation relation and target performance level (FEMA-356-2000) [8].

\section{Performance Based Design}

It is a design method used for assessing the response of the building to the future seismic events and deciding whether such response meets the specific performance demands. The performance levels of the buildings due to seismic loads are as (FEMA-356-2000) [8]. According to FEMA-356, pushover analysis displays the load-displacement curve for beams and columns critical sections that form a nonlinear plastic hinge. This curve is shown in Figure 4. While Table 2 shows the Performance Level of Building and the resulted damage for each level. 
Table 2. Performance Level of Building [8].

\begin{tabular}{cl}
\hline Level & \multicolumn{1}{c}{ Resulted damage description } \\
\hline $\begin{array}{c}\text { Operational } \\
(\mathrm{O})\end{array}$ & $\begin{array}{l}\text { Very simple light damage, no permanent displacement, structure returns to its } \\
\text { own strength and stiffness after load removing. }\end{array}$ \\
$\begin{array}{cl}\text { Immediate } \\
\text { occupancy (IO) }\end{array}$ & $\begin{array}{l}\text { Light damage, no permanent displacement, structure returns to its own strength } \\
\text { and stiffness after load removing, elevator can be restarted, fire protection } \\
\text { operable }\end{array}$ \\
$\begin{array}{c}\text { Life safety } \\
\text { (LS) }\end{array}$ & $\begin{array}{l}\text { Moderate damage, some permanent displacement, some residual stiffness and } \\
\text { strength still in the structure stories, damage to partitions, building may need } \\
\text { large repairing cost. }\end{array}$ \\
$\begin{array}{c}\text { Collapse } \\
\text { prevention } \\
\text { (CP) }\end{array}$ & $\begin{array}{l}\text { Severe damage, large displacement, little residual stiffness and strength, structure } \\
\text { is close to collapse. }\end{array}$ \\
\hline
\end{tabular}

\section{Cracking Limit State}

According to design aids and examples in accordance with the (ECP-203-2007) [9] code when designing reinforced concrete structures, one should fulfill the following relations:

$$
\begin{gathered}
W_{k}=\beta \cdot S_{r m} \cdot \varepsilon_{s m}(\mathrm{~mm}) \\
S_{r m}=\left[50+0.25 K_{1} K_{2} \frac{\phi}{\rho_{r}}\right](\mathrm{mm}) \\
\varepsilon_{s m}=\frac{F_{s}}{E_{s}}\left[1-\beta_{1} \beta_{2}\left(\frac{F_{s r}}{F_{s}}\right)^{2}\right]
\end{gathered}
$$

where, $W_{k}$ is the crack width value in $(\mathrm{mm}) . S_{r m}$ is the Spacing between cracks in the horizontal direction measured in $(\mathrm{mm}) . \boldsymbol{\varepsilon}_{s m}$ is the mean steel strain under a relevant combination of loads and allowing for the effect such as tension stiffening or shrinkage. $\beta$ is the Coefficient that connects the average crack width to the design crack width. $\Phi$ is the Bar diameter in $(\mathrm{mm}), \beta_{1}$ is a coefficient that reflects the bond properties of the reinforcing steel bars. $\beta_{2}$ is a coefficient that reflects the loading duration. $K_{1}$ is a coefficient that reflects the type of steel bars. $K_{2}$ is a coefficient that shows the distribution of the strain over the subjected cross section.

$$
K_{2}=\varepsilon_{1}+\varepsilon_{2} / 2 \varepsilon_{2}
$$

where, $\varepsilon_{2}$ and $\varepsilon_{1}$ are the minimum and maximum strain values on the subjected section, and shall be calculated according to the analysis of a cracked section.

$$
\rho_{r}=\frac{A_{s}}{A_{c e f}}
$$

where, $A_{s}$ is the area of longitudinal tension steel within the effective tension 
area. $A_{c e f}$ is the area of effective concrete section in tension = width of the section $\times t_{c e f} . t_{c e f}=2.5 \times$ concrete cover. $F_{s}$ is the stress in longitudinal steel bars at the tension zone calculated based on the analysis of cracked section under permanent loads. $F_{s r}$ is the stress in longitudinal steel bars located in the tension zone calculated according to the analysis of cracked section due to the loads that causing first crack.

\section{Calculation of Crack Width and Crack Length for Beams}

Figure 4 The plastic moment in beams due to earthquake and the crack mechanism according to this moment.

The moment $M_{t}$ and $M_{b}$ values describe the damage level and its suitable repairing method, the normal force values in beams is small and can be neglected. By taking the average moment at the top and bottom (reversible moment). According to ECP code [9], we can get the crack width $\left(W_{k}\right)$, the horizontal distance between the cracks $\left(S_{r m}\right)$, and the vertical distance between the neutral axis and the maximum tensile stress. From the value of $\left(S_{r m}\right)$ and the vertical distance between the neutral axis and the maximum tensile stress, the whole length of cracks that will be injected with epoxy can be calculated.

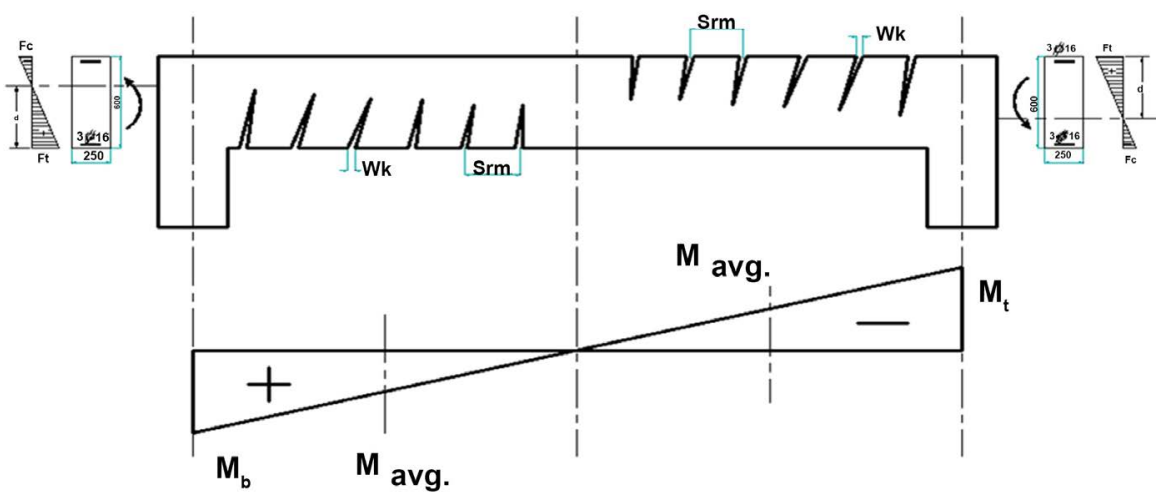

Figure 4. The plastic moment in beams due to earthquake and the crack mechanism according to this moment.

\section{The Methodology of the Study}

\section{Description of the Case Study Building}

The prototype building consists of 7-story framed reinforced concrete structure, with a story height of $3.0 \mathrm{~m}$, the overall plan is $12 \mathrm{~m} \times 12 \mathrm{~m}\left(144 \mathrm{~m}^{2}\right)$. Figure 5(a) and Figure 5(b) show the typical slab layout and slab reinforcement distribution, respectively.

The structural system was designed using a design practice that considers gravity loads and linear static seismic loads according to ECP code (ECP-201-2012) [5] by using SAP2000 software(Computer and Structures 2014) [10]. A summary of the model's assumptions is presented in Table 3. Figure 6 shows the three-dimensional model of the structure. 


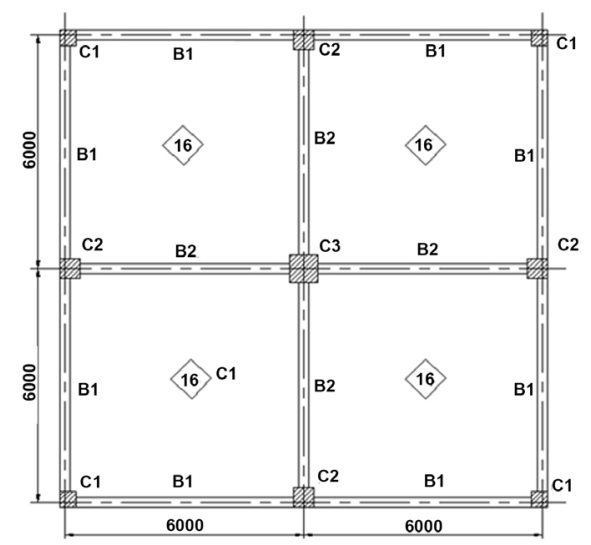

(a)

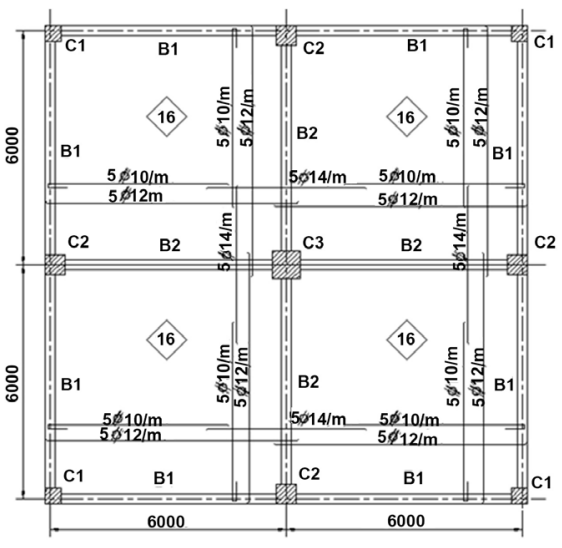

(b)

Figure 5. (a) Slab layout; (b) Slab reinforcement.

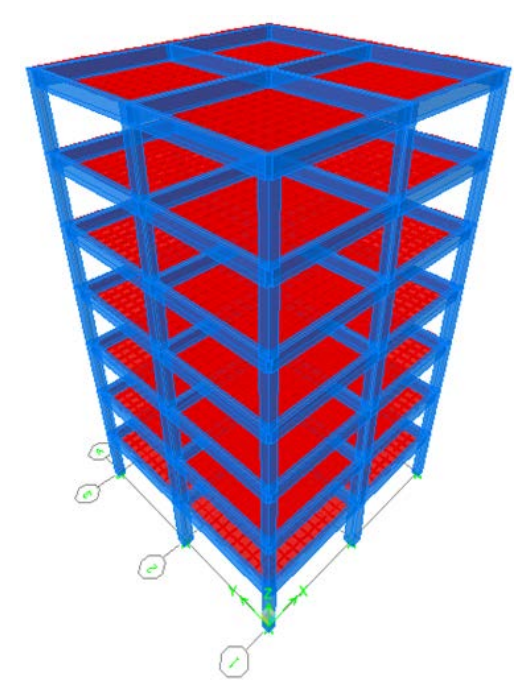

Figure 6. 3d Model SAP 2000 structure layout.

Table 3. Assumptions of the model.

\begin{tabular}{cc}
\hline Material & $25 \mathrm{~N} / \mathrm{mm}^{2}(\mathrm{MPa})$ \\
\hline Concrete & $360 / 520$ for main bars \& $240 / 350$ for confinement bars \\
Steel & \\
\hline Loads & Calculated by the program \\
\hline Own weight & $5 \mathrm{KN} / \mathrm{m}^{2}$ \\
Dead load & $2 \mathrm{KN} / \mathrm{m}^{2}$ \\
Live load & Not Considered \\
Wind load & As mentioned below \\
Seismic load & Non Linear frame element for beam and column \\
Modeling & Shell element for slab \\
Nlements & Not considered \\
P-delta effect & Rigid diaphragm for slab \\
Diaphragm & Fixed \\
Support type & \\
\hline
\end{tabular}




\subsection{Case Study (1)}

The building designed to resist vertical loads only which are the dead loads and live loads. By using AutoCAD program (Autodesk 2014) [12] for drawings, the beams dimensions and reinforcement are shown in Table 4. The column dimensions and reinforcement details are shown in Figure 7 (Table 5). (Table 6) shows the footing and tie beams dimensions.

\subsubsection{Design Results}

1) Construction bill of quantities for the designed structure

The cost of the structural works needed for construction is shown in Table 7.

2) Performance based analysis for the designed structure

The performance based analysis is performed by nonlinear static pushover analysis that is implemented using the SAP2000 software (Computer and Structures 2014) [10]. The force on each floor used for pushover analysisis shown in Table 8.

\subsubsection{Capacity Curve}

The load-displacement capacity curve resulted is shown in Figure 8.

\subsubsection{Plastic Hinge Mechanism}

At each pushover analysis step obtain the location of hinges in the structural elements, plastic hinges rotation and hinges reached to the FEMA provisions, which are IO, LS, and CP identified by using colored plastic hinges as shown in Figure 9. The building elevations are numbered as shown in Figure 10.

\subsubsection{Plastic Moment at Collapse in (ton $\cdot \mathrm{m}$ )}

For columns at step 5 as shown in Figure 11.

For beams at step 5 as shown in Figure 12.

Axial for cein(t) for columns at step 5 is shown in Figure 13.

\subsubsection{Crack Width for Beams and Columns after Earthquake in ( $\mathrm{mm}$ )}

By using equation of the (ECP-203) [9] code, the crack width values for beams and columns are shown in Figure 14.

Red color means that the steel is yielded and Green color means that the steel is not yielded.

By using the ECP-203 code [9] equations we can calculate the:

- Spacing between cracks in beams for calculation of the length of cracks needed to be injected with epoxy $=20 \mathrm{~cm}$.

By using an excel sheet that constructed for calculation of section's moment capacity:

Moment capacity for beam B1 $=10.1 \mathrm{t} \cdot \mathrm{m}$ and for beam B2 $=16.6 \mathrm{t} \cdot \mathrm{m}$.

- Neutral axis height for calculation of the length of cracks needed to be injected by epoxy $=36 \mathrm{~cm}$. 
Table 4. Beams dimensions and reinforcement.

\begin{tabular}{|c|c|c|c|c|c|c|c|c|c|c|}
\hline \multirow{2}{*}{$\begin{array}{c}\text { EAM } \\
\text { MARK }\end{array}$} & \multirow{2}{*}{$\begin{array}{l}\text { SIZE } \\
(B X D)\end{array}$} & \multicolumn{3}{|c|}{$\begin{array}{c}\text { BOTTOM } \\
\text { REINFORCEMENT }\end{array}$} & \multicolumn{3}{|c|}{$\begin{array}{c}\text { TOP } \\
\text { REINFORCEMENT }\end{array}$} & \multicolumn{3}{|c|}{ LINKS } \\
\hline & & LEFT & $\begin{array}{l}\text { MID } \\
\text { SPAN }\end{array}$ & RIGHT & LEFT & $\begin{array}{l}\text { MID } \\
\text { SPAN }\end{array}$ & RIGHT & LEFT & $\begin{array}{l}\text { MID } \\
\text { SPAN }\end{array}$ & RIGHT \\
\hline B1 & $250 \times 600$ & $3 \mathrm{~T} 16$ & $3 \mathrm{~T} 16$ & $3 \mathrm{~T} 16$ & $3 \mathrm{~T} 16$ & $2 \mathrm{~T} 16$ & $3 \mathrm{~T} 16$ & $5 \varnothing 8 / \mathrm{m}$ & $5 ø 8 / \mathrm{m}$ & $5 \varnothing 8 / \mathrm{m}$ \\
\hline B2 & $250 \times 600$ & $5 \mathrm{~T} 16$ & $5 \mathrm{~T} 16$ & $5 \mathrm{~T} 16$ & $8 \mathrm{~T} 16$ & $4 \mathrm{~T} 12$ & $8 \mathrm{~T} 16$ & $8 ø 10 / \mathrm{m}$ & $5 ø 8 / \mathrm{m}$ & $8 ø 10 / \mathrm{m}$ \\
\hline
\end{tabular}

Table 5. Footing dimensions and reinforcement.

\begin{tabular}{ccccccccccc}
\hline \multicolumn{10}{c}{ SCHEDULE OF ISOLATED FOOTINGS } \\
\hline FOOTING \\
MARK
\end{tabular}

Table 6. Tie beams dimensions and reinforcement.

\begin{tabular}{cccccc}
\hline \multirow{2}{*}{ TYPE } & \multirow{2}{*}{$\begin{array}{c}\text { DIMENSIONS } \\
\mathrm{b} \times \mathrm{t}(\mathrm{mm})\end{array}$} & BOTTOM & TOP & SIDE & STIRRUPS \\
\cline { 3 - 6 } & $250 \times 700$ & $4 \mathrm{~T} 16$ & $4 \mathrm{~T} 16$ & --- & $5 ø 8 / \mathrm{m}$ \\
\hline
\end{tabular}

Table 7. Cost of structural works.

\begin{tabular}{cccccc}
\hline Item & $\begin{array}{c}\text { Volume } \\
\left(\mathrm{m}^{3}\right)\end{array}$ & $\begin{array}{c}\text { Contractor } \\
\text { fees (Pounds) }\end{array}$ & $\begin{array}{c}\text { Material cost } \\
\text { (Pounds) }\end{array}$ & $\begin{array}{c}\text { Supervision } \\
\text { percentage (\%) }\end{array}$ & $\begin{array}{c}\text { Losses } \\
\text { percentage (\%) }\end{array}$ \\
\hline $\begin{array}{c}\text { Plain Concrete } \\
\text { Reinforced } \\
\text { Concrete }\end{array}$ & 30.32 & 130 & 690 & 10 & 3 \\
\hline
\end{tabular}

Total construction cost $=890529 \mathrm{~L} \cdot \mathrm{E}$, Total construction cost $/ \mathrm{m}^{2}$ of floor $=883.46 \mathrm{~L} \cdot \mathrm{E} / \mathrm{m}^{2}$.

Table 8. The force on each floor used for pushover analysis.

\begin{tabular}{ccccc}
\hline Floor & hi $(\mathrm{m})$ & Fi (t) & Shear (t) & Moment (t.m) $=$ hi $\times$ Fi \\
\hline 7 & 21 & 11.57 & 11.571 & 243 \\
6 & 18 & 9.918 & 21.489 & 178.524 \\
5 & 15 & 8.265 & 29.754 & 123.975 \\
4 & 12 & 6.612 & 36.366 & 49.344 \\
3 & 9 & 4.959 & 41.325 & 44.631 \\
2 & 6 & 3.306 & 44.631 & 4.836 \\
1 & 3 & 1.653 & 46.284 & 4.959 \\
\hline
\end{tabular}




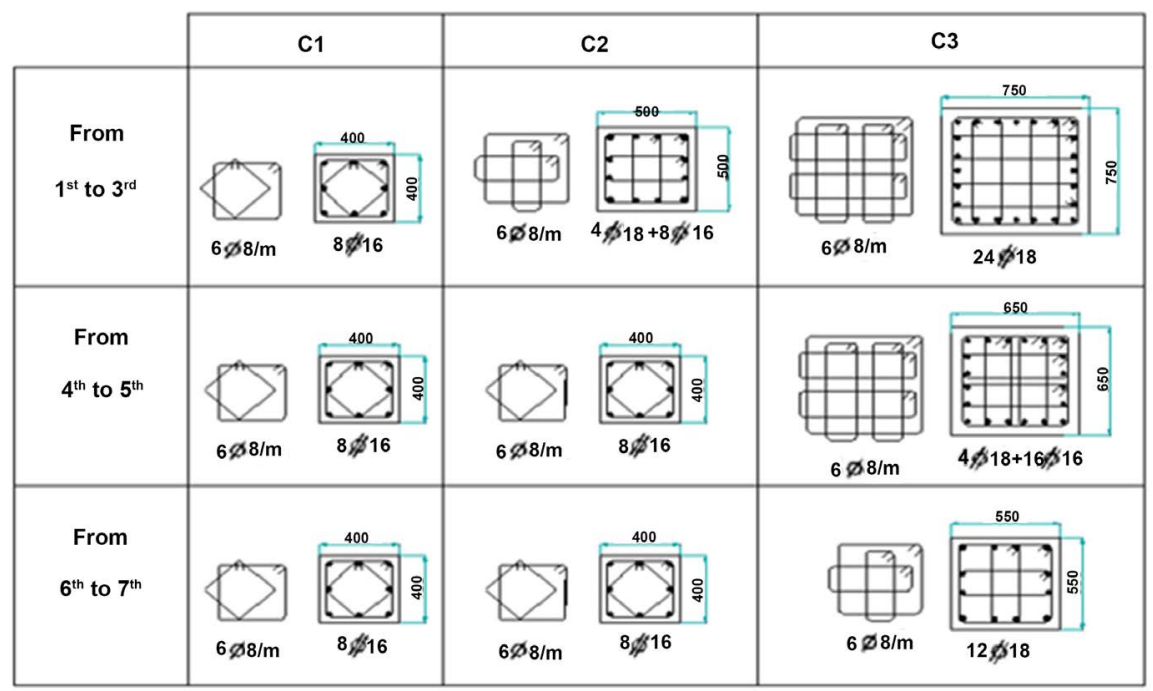

Figure 7. Columns dimensions and reinforcement.

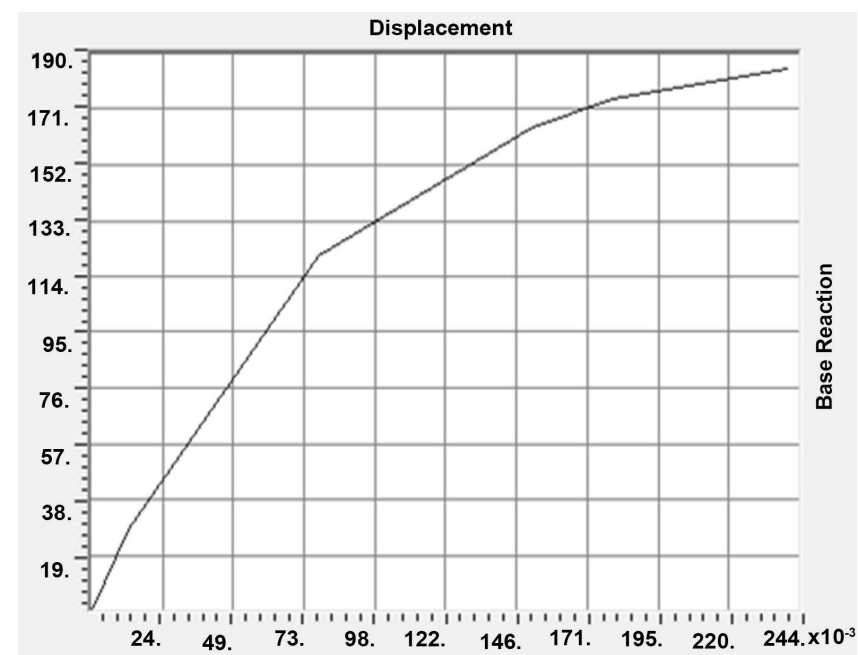

Figure 8. Pushover curve for the building in $\mathrm{x}, \mathrm{y}$ directions $(\mathrm{t} \cdot \mathrm{m})$.

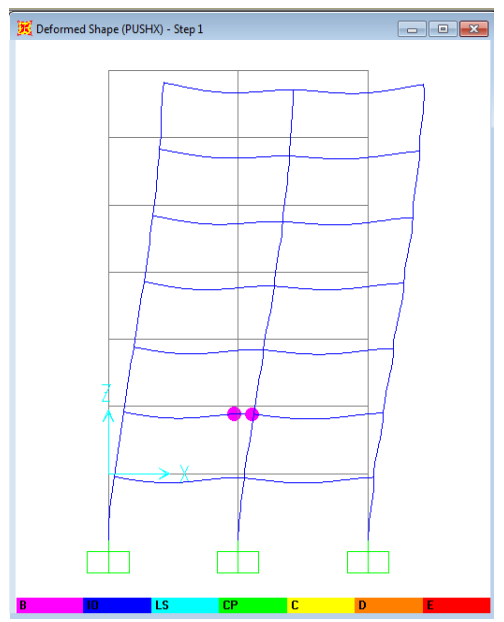

(a) 


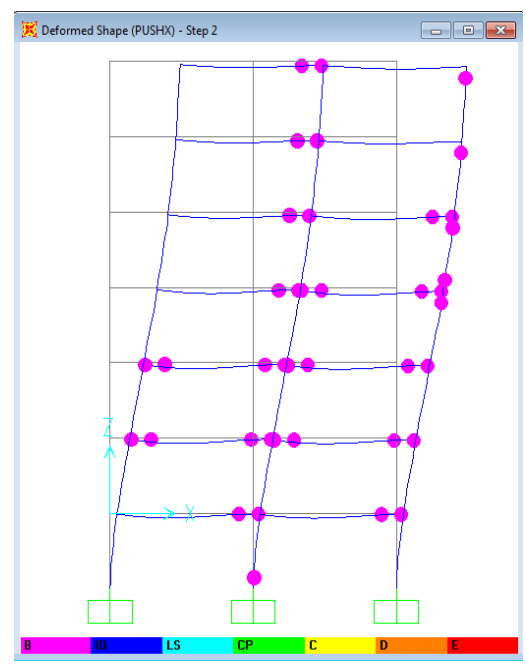

(b)

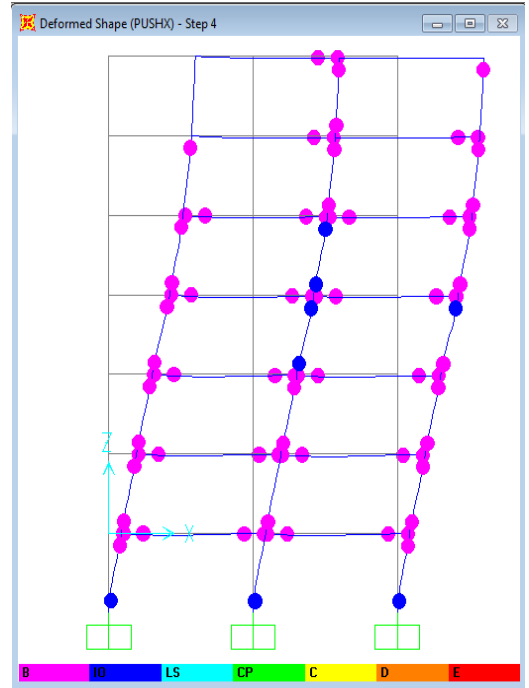

(d)

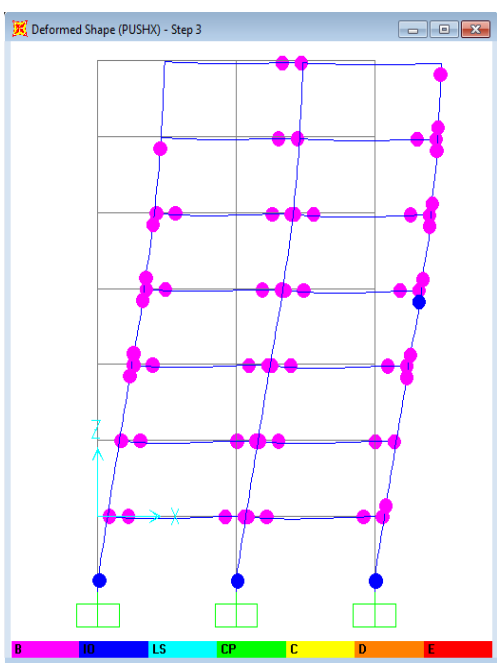

(c)

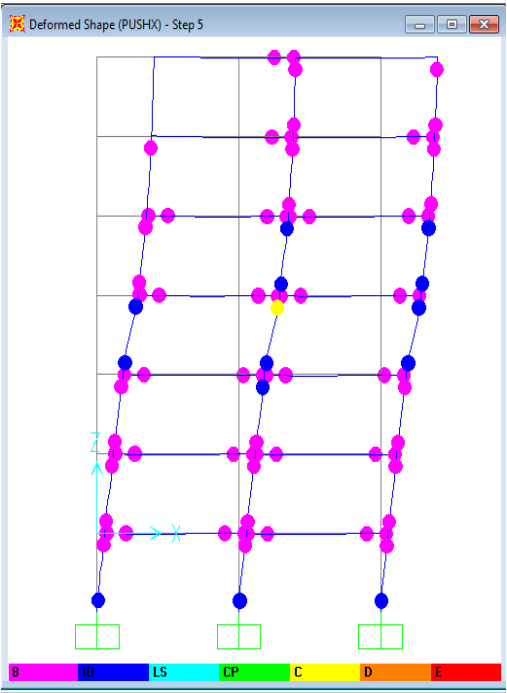

(e)

Figure 9. (a) Plastic hinge pattern at step 1 (Elevation 3); (b) Plastic hinge pattern at step 2 ( Elevation 2); (c) Plastic hinge pattern at step 3 (Elevation 2); (d) Plastic hinge pattern at step 4 (Elevation 3); (e) Plastic hinge pattern at step 5 (Elevation 3).

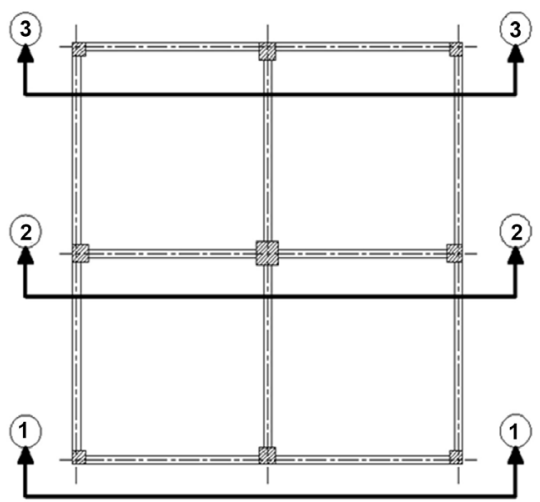

Figure 10. Key plan for building elevations. 


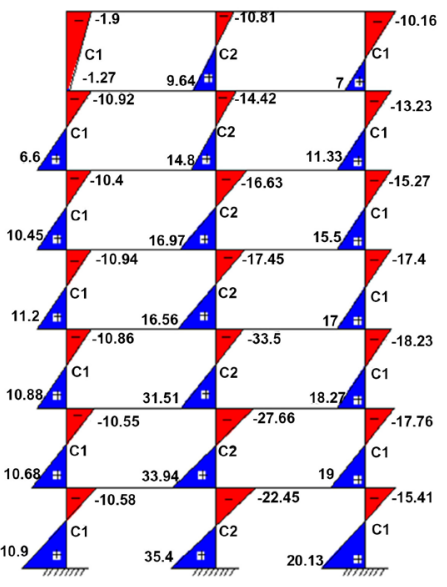

(a)

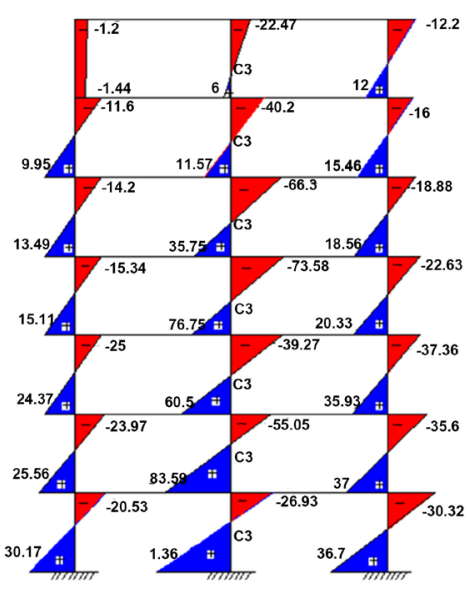

(b)

Figure 11. (a) Moment at elevations 1 \& 3; (b) Moment at elevation 2.

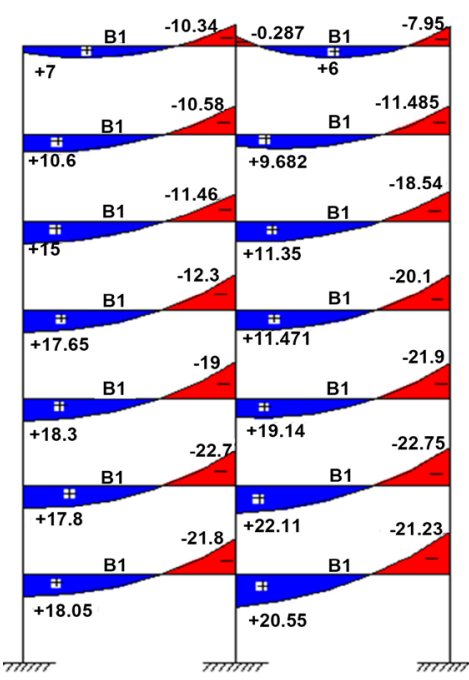

(a)

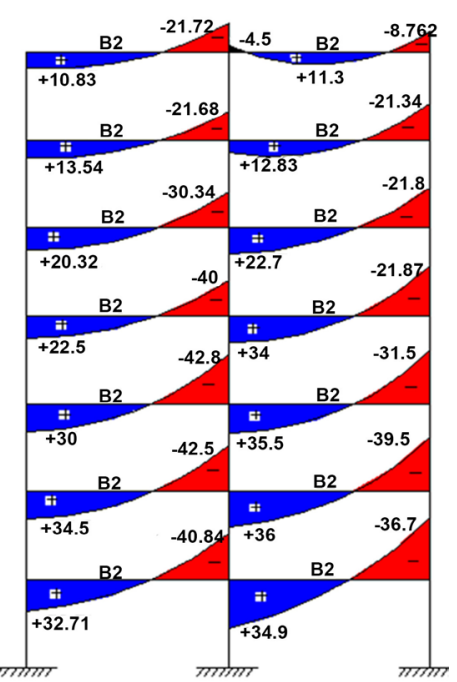

(b)

Figure 12. (a) Moment at elevations 1 \& 3; (b) Moment at elevation 2.

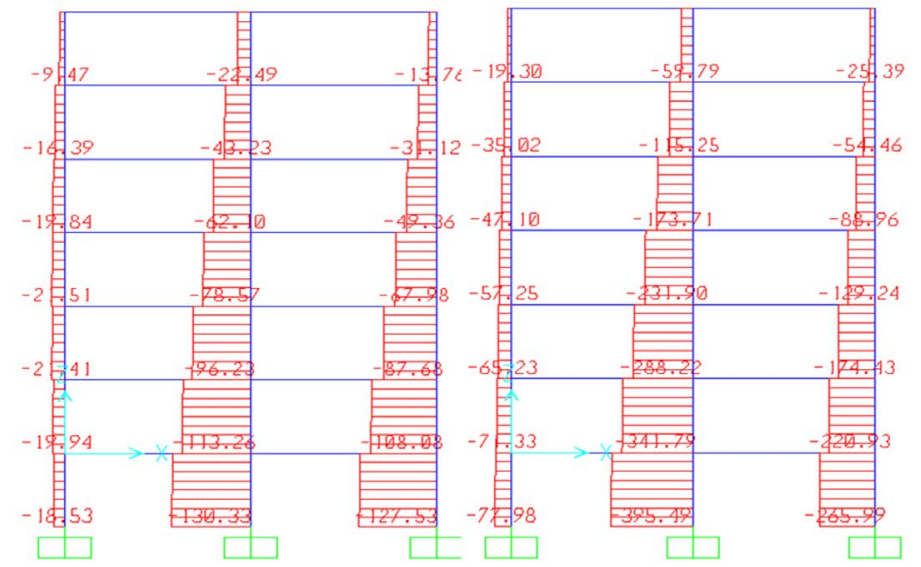

(a)

(b)

Figure 13. (a) Axial force at elevations 1 \& 3; (b) Axial force at elevation 2. 


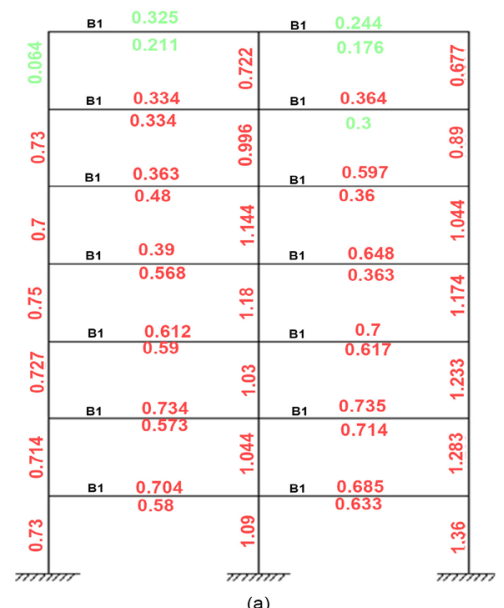

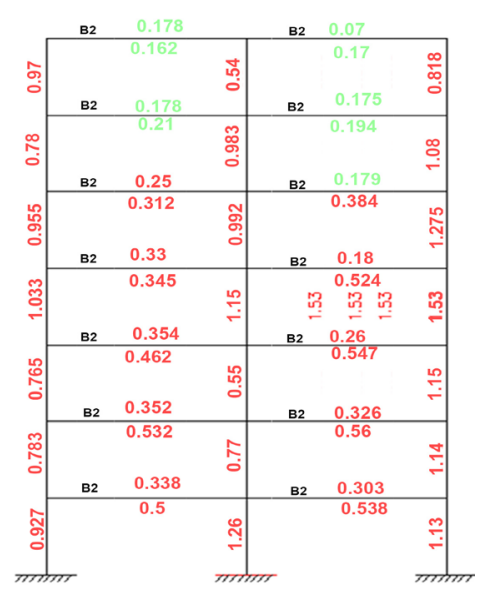

(b)

Figure 14. (a) Crack width at elevations 1 \& 3; (b) Crack width at elevation 2.

\subsection{Case Study (2)}

The building is designed to resist vertical loads and static linear seismic loads in accordance with ECP-201 [5]. The seismic zone considered in this study is zone 3 (Cairo) where $a_{g}=0.15 \mathrm{~g}$, and the response spectrum shape is type 1 , the building facility is a residential building, its importance factor $\gamma=1$, the soil type under the building is considered to be stiff soil, which presents soil class $C$ and the soil factor $S=1.5$. The ductility reduction factor $R$, is taken as $R=5$ considering that the vertical loads and the total base shear force a re totally resisted by the non-ductile frame structural system. The beams dimensions and reinforcement are shown in (Table 9) Table 10. The column dimensions and reinforcement details are shown in Figure 15. (Table 11), (Table 6) shows the footing and tie beams dimensions.

Earthquake loads according to ECP (2012)

A residential building located in Cairo, Egypt, soil class c, zone 3, h floor $=3$ $\mathrm{m}, \mathrm{n}$ floors $=7$, response spectrum type 1 .

For soil class $\mathrm{C}$

$S=1.5, T_{B}=0.1, T_{C}=0.25, T_{D}=1.2, C_{t}=0.075 \quad$ (R.C. Structure)

$T=C_{t} \times H \frac{3}{4}=0.075 \times 21 \times \frac{3}{4}=0.7357$ seconds $<4 T_{C}=4 \times 0.25=1 \mathrm{sec}$.

For concrete framed structure (residential)

$$
\begin{aligned}
\gamma=1, \eta=1, \text { For } T_{C} \leq T \leq T_{D} \rightarrow S_{d}(T)=\left[\frac{2.5}{R}\right] \times a_{g} \times \gamma, \\
R=5 \times S \times \eta\left[\frac{T C}{T}\right] \geq 0.2 \times a_{g} \times \gamma \\
S_{d}(T)=\left[\frac{2.5}{5}\right] \times(0.15 \times 9.81) 1 \times 1.5 \times 1 \times\left[\frac{0.25}{0.7357}\right] \\
=0.375 \geq 0.2 \times a_{g} \times \gamma=0.2943
\end{aligned}
$$

Calculation of weight for all floors

$W_{\text {slab+beams }}=1.04 \times 12 \times 12 \times 7=1048.32 \mathrm{t}$, 


$$
\begin{aligned}
& W_{\text {columns }}=[(4 \times 0.4 \times 0.4)+(4 \times 0.5 \times 0.5)+(0.7 \times 0.7)] \times 2.5 \times 21=111.825 \mathrm{t}, \\
& W_{\text {dead }}=1048.32+111.825=1160.145 \mathrm{t}, \quad W_{\text {live }}=0.2 \times 12 \times 12 \times 7=201.6 \mathrm{t}, \\
& W_{\text {total }}=W_{D}+0.25 W_{L}=1210.55 \mathrm{t}, \quad W_{\text {floor }}=172.94 \mathrm{t}
\end{aligned}
$$

Calculation of total base shear force and the horizontal force on each floor

$$
\begin{aligned}
& F_{b}=\gamma \times S_{d}(T) \times \lambda \times W / g=0.375 \times 1 \times(1210.55 / 9.81)=46.275 \mathrm{t} \\
& \sum W_{i} h_{i}=172.94(3+6+9+12+15+18+21)=14526.96 \mathrm{t} \cdot \mathrm{m}, \\
& F_{i}=\left[\frac{h_{i} \times W_{i}}{\sum_{j=1}^{n} h_{j} \times W_{j}}\right] \times F_{b}=46.275 \times\left[\frac{h_{i} \times 172.94}{14526.96}\right]=0.551 h_{i}
\end{aligned}
$$

\subsubsection{Design Results}

1). Construction bill of quantities for the designed structure

The cost of the structural works needed for construction is shown in (Table 12) Table 13.

2) Performance based analysis for the designed structure

The performance based analysis is performed by nonlinear static pushover analysis that is implemented using the SAP2000 software (Computer and Structures 2014) [10]. The force on each floor used for pushover analysis is shown in Table 9.

\subsubsection{Capacity Curve}

The load-displacement capacity curve resulted is shown in Figure 16.

\subsubsection{Plastic Hinge Mechanism}

At each pushover analysis step obtain the location of hinges in the structural elements, plastic hinges rotation and hinges reached to the FEMA provisions, which are IO, LS, and CP identified by using colored plastic hinges as shown in Figure 17. The building elevations are numbered as shown in Figure 10.

\subsubsection{Plastic Moment at Collapse in (ton $\cdot \mathrm{m}$ )}

For columns at step 5 as shown in Figure 18.

For beams at step 5 as shown in Figure 21.

Axial force in (t) for columns at step 5 as shown in Figure 19.

\subsubsection{Crack Width Values for Beams and Columns after the Earthquake Occurrence in ( $\mathrm{mm})$}

By using equations of the (ECP-203) [9] code, the crack width values for beams and columns are shown in Figure 20.

Red color means that the steel is yielded Green color means that the steel is not yielded.

By using the ECP-203 code [9] equations we can calculate the:

- Spacing between cracks in beams for calculation of the length of cracks needed to be injected with epoxy $=12 \mathrm{~cm}$.

By using an excel sheet that constructed for calculation of section's moment capacity:

- Moment capacity for beam B1 $=10.06 \mathrm{t} \cdot \mathrm{m}$ and for beam B2 $=16.6 \mathrm{t} \cdot \mathrm{m}$.

- Neutral axis height for calculation of the length of cracks needed to be injected by epoxy $=28 \mathrm{~cm}$. 
Table 9. The force on each floor used for pushover analysis.

\begin{tabular}{ccccc}
\hline Floor & hi $(\mathrm{m})$ & Fi $(\mathrm{t})$ & Shear $(\mathrm{t})$ & Moment $(\mathrm{t} \cdot \mathrm{m})=\mathrm{hi} \times \mathrm{Fi}$ \\
\hline 7 & 21 & 11.57 & 11.571 & 243 \\
6 & 18 & 9.918 & 21.489 & 178.524 \\
5 & 15 & 8.265 & 29.754 & 123.975 \\
4 & 12 & 6.612 & 36.366 & 79.344 \\
3 & 9 & 4.959 & 41.325 & 44.631 \\
2 & 6 & 3.306 & 44.631 & 19.836 \\
1 & 3 & 1.653 & 46.284 & 4.959 \\
\hline
\end{tabular}

Table 10. Beams dimensions and reinforcement.

\begin{tabular}{|c|c|c|c|c|c|c|c|c|c|c|}
\hline \multirow{2}{*}{$\begin{array}{l}\text { BEAM } \\
\text { MARK }\end{array}$} & \multirow{2}{*}{$\begin{array}{l}\text { SIZE } \\
(\mathrm{BXD})\end{array}$} & \multicolumn{3}{|c|}{$\begin{array}{c}\text { BOTTOM } \\
\text { REINFORCEMENT }\end{array}$} & \multicolumn{3}{|c|}{$\begin{array}{c}\text { TOP } \\
\text { REINFORCEMENT }\end{array}$} & \multicolumn{3}{|c|}{ LINKS } \\
\hline & & LEFT & $\begin{array}{l}\text { MID } \\
\text { SPAN }\end{array}$ & RIGHT & LEFT & $\begin{array}{l}\text { MID } \\
\text { SPAN }\end{array}$ & RIGHT & LEFT & $\begin{array}{l}\text { MID } \\
\text { SPAN }\end{array}$ & RIGHT \\
\hline B1 & $250 \times 600$ & $3 \mathrm{~T} 16$ & $3 \mathrm{~T} 16$ & $3 \mathrm{~T} 16$ & $5 \mathrm{~T} 16$ & $3 \mathrm{~T} 16$ & $5 \mathrm{~T} 16$ & $5 ø 8 / \mathrm{m}$ & $5 \varnothing 8 / \mathrm{m}$ & $5 ø 8 / \mathrm{m}$ \\
\hline B2 & $250 \times 600$ & $5 \mathrm{~T} 16$ & 5T16 & $5 \mathrm{~T} 16$ & $8 \mathrm{~T} 16$ & $4 \mathrm{~T} 12$ & $8 \mathrm{~T} 16$ & $8 ø 12 / \mathrm{m}$ & $8 ø 8 / \mathrm{m}$ & $8 ø 12 / \mathrm{m}$ \\
\hline
\end{tabular}

Table 11. Footing dimensions and reinforcement.

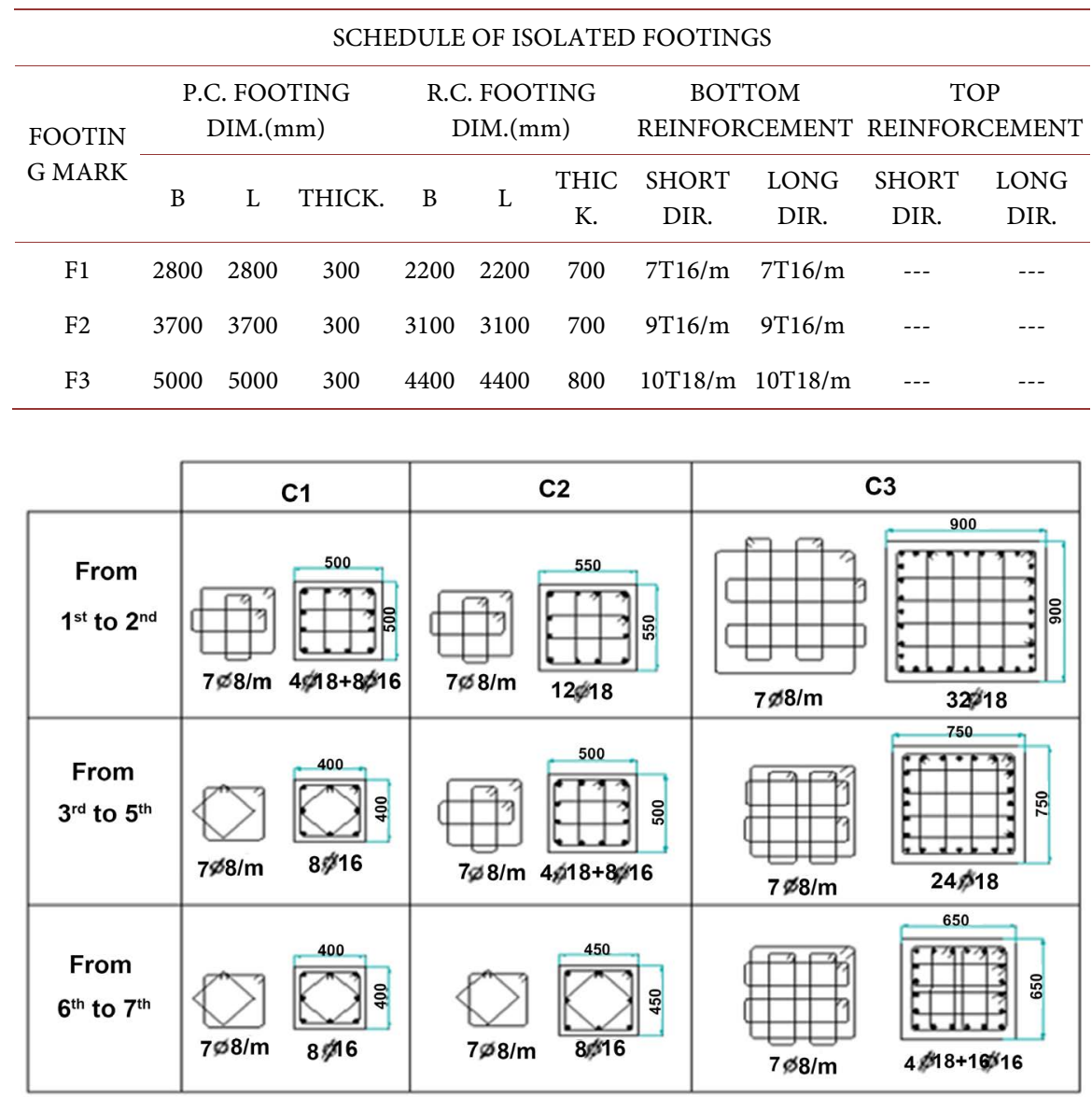

Figure 15. Columns dimensions and reinforcement. 
Table 12. Cost of structural works.

\begin{tabular}{cccccc}
\hline Item & $\begin{array}{c}\text { Volume } \\
\left(\mathrm{m}^{3}\right)\end{array}$ & $\begin{array}{c}\text { Contractor fees } \\
(\text { Pounds })\end{array}$ & $\begin{array}{c}\text { Material cost } \\
\text { (Pounds) }\end{array}$ & $\begin{array}{c}\text { Supervision } \\
\text { percentage (\%) }\end{array}$ & $\begin{array}{c}\text { Losses percentage } \\
(\%)\end{array}$ \\
\hline Plain Concrete & 33.34 & 130 & 690 & 10 & 3 \\
$\begin{array}{c}\text { Reinforced } \\
\text { Concrete }\end{array}$ & 329.05 & 330 & 690 & 10 & 3 \\
\hline
\end{tabular}

Total construction cost $=957737 \mathrm{~L} \cdot \mathrm{E}$, Total construction cost $/ \mathrm{m}^{2}$ of floor $=950.14 \mathrm{~L} \cdot \mathrm{E} / \mathrm{m}^{2}$.

Table 13. The force on each floor, shear force and overturning moment.

\begin{tabular}{ccccc}
\hline Floor & hi $(\mathrm{m})$ & Fi (t) & Shear $(\mathrm{t})$ & Moment $(\mathrm{t} \cdot \mathrm{m})=\mathrm{hi} \times \mathrm{Fi}$ \\
\hline 7 & 21 & 57.855 & 57.855 & 1215 \\
6 & 18 & 49.59 & 107.445 & 892.62 \\
5 & 15 & 41.325 & 148.77 & 619.875 \\
4 & 12 & 33.06 & 181.83 & 396.72 \\
3 & 9 & 24.795 & 206.625 & 223.155 \\
2 & 6 & 16.53 & 223.155 & 99.18 \\
1 & 3 & 8.265 & 231.42 & 24.795
\end{tabular}

Base shear force $=231.42 \mathrm{t}$, Overturning moment $=3471.35 \mathrm{t} \cdot \mathrm{m}$.

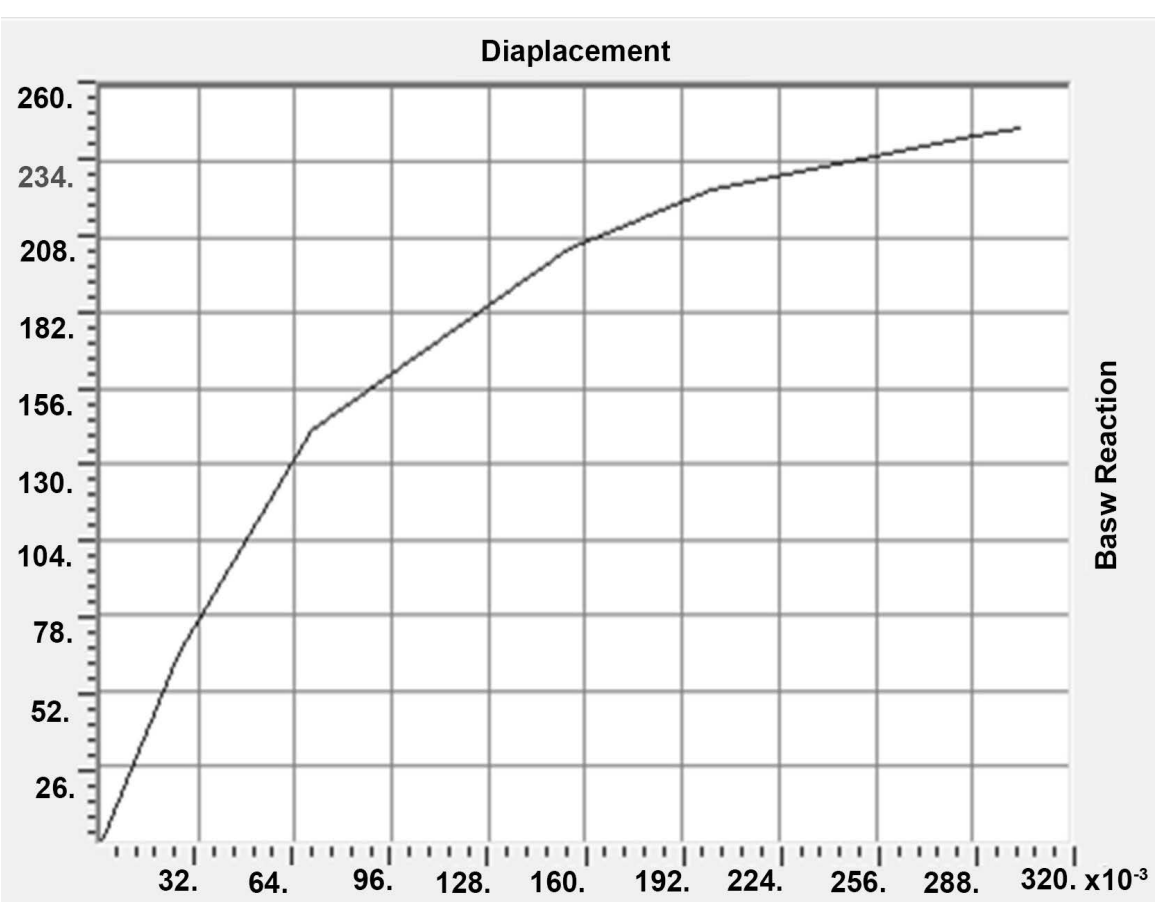

Figure 16. Pushover curve for the building in $\mathrm{x}, \mathrm{y}$ directions $(\mathrm{t} \cdot \mathrm{m})$. 


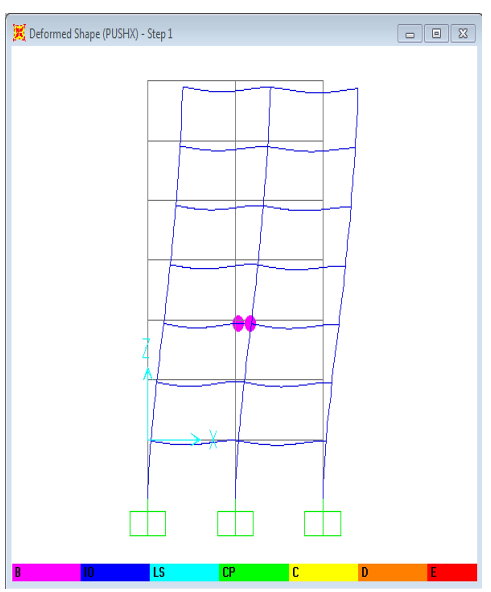

(a)

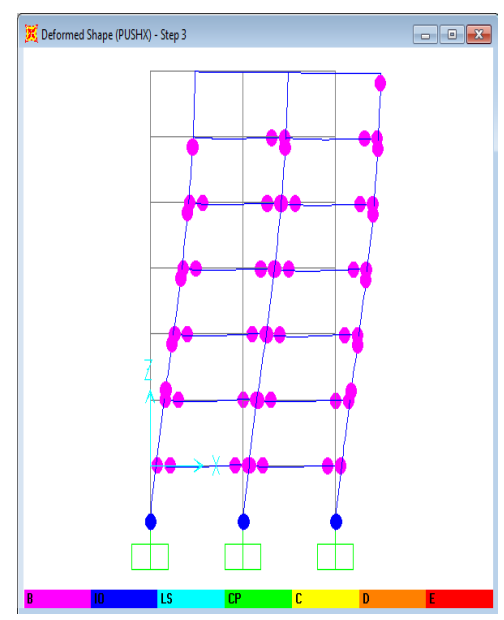

(c)

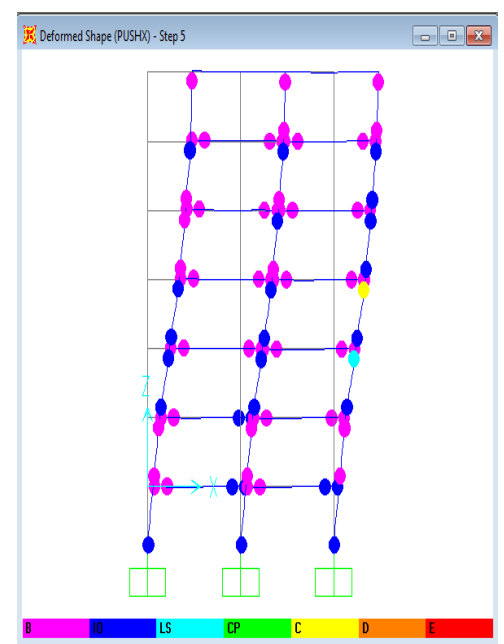

(e)

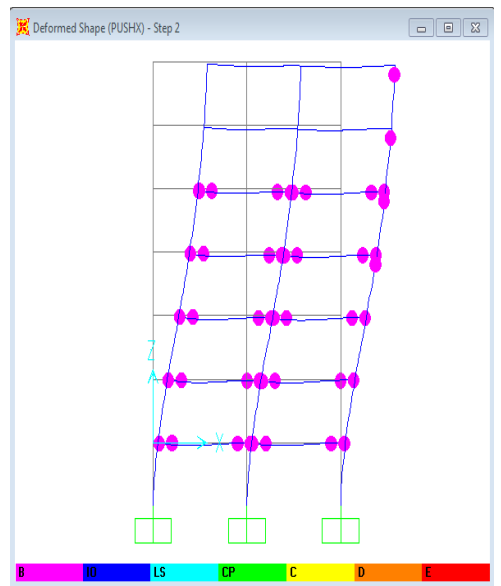

(b)

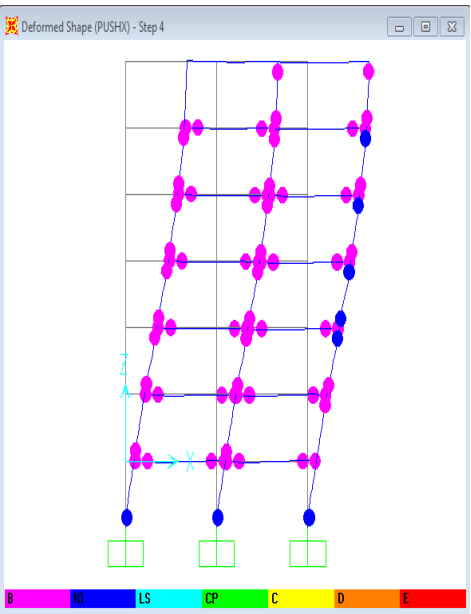

(d)

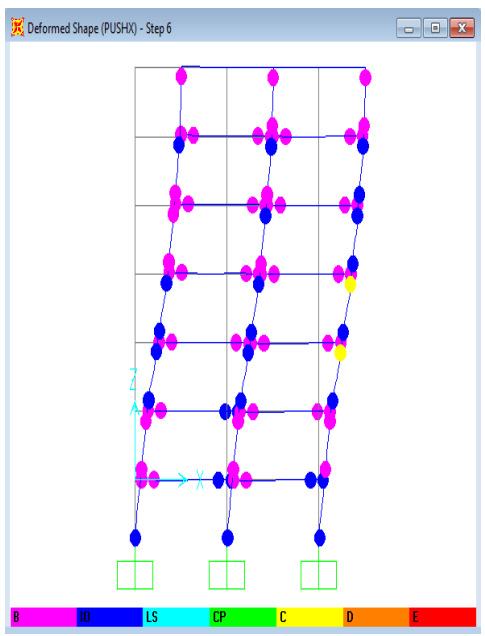

(f)

Figure 17. (a) Plastic hinge pattern at step 1 (Elevation 3); (b) Plastic hinge pattern at step 2( Elevation 2); (c) Plastic hinge pattern at step 3 (Elevation 2); (d) Plastic hinge pattern at step 4 (Elevation 3); (e) Plastic hinge pattern at step 5 (Elevation 3); (f) Plastic hinge pattern at step 6 (Elevation 3). 

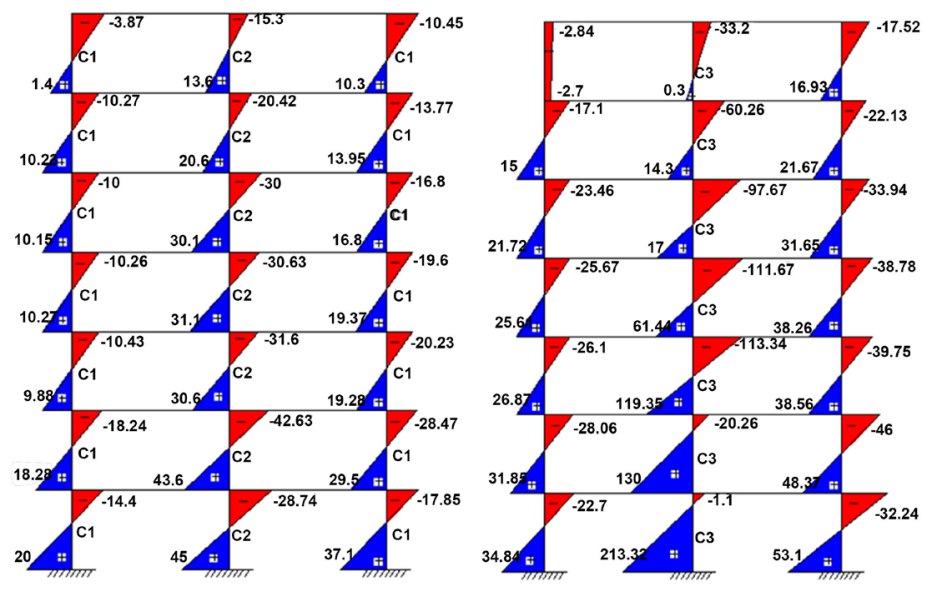

(a)

(b)

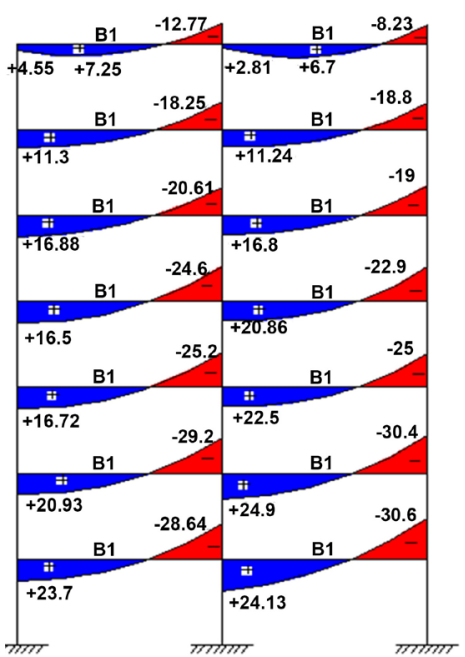

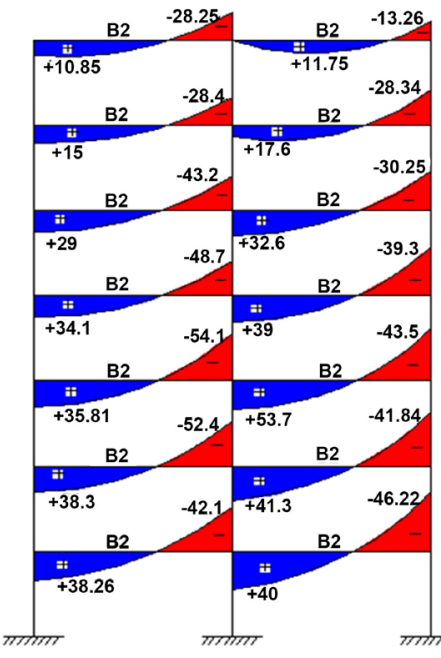

(d)

Figure 18. (a) Moment at elevations 1; (b) Moment at elevation 2; (c) Moment at elevations 1 \& 3; (b) Moment at elevation 2.

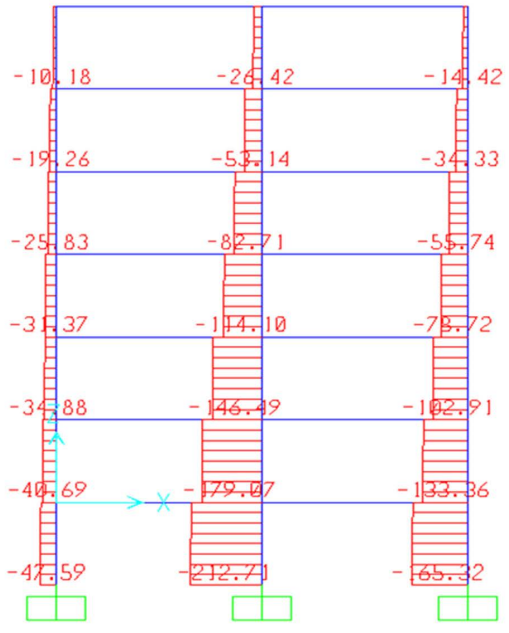

(a)

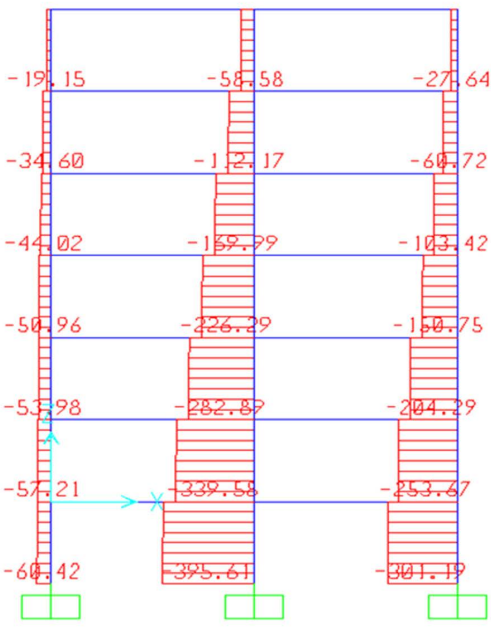

(b)

Figure 19. (a) Axial force at elevations 1 \& 3; (b) Axial force at elevation 2. 


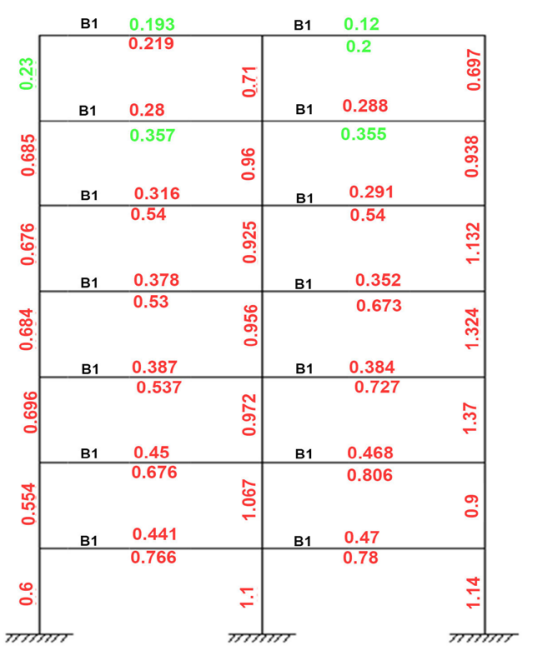

(a)

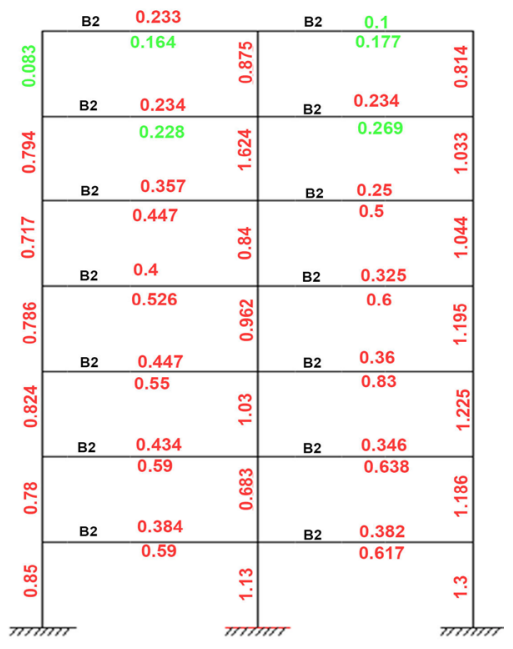

(b)

Figure 20. (a) Crack width at elevations 1 \& 3; (b) Crack width at elevation 2.

\subsection{Case Study (3)}

The building is designed to resist vertical loads and static linear seismic loads in accordance with ECP-201 [5]. The seismic zone considered in this study is zone 3 (Cairo) where $a_{g}=0.15 \mathrm{~g}$, and the shape of the response spectrum is type 1 , the building facility is a residential building with an importance factor $\gamma=1$, the soil type under the building is considered to be stiff soil, which presents soil class $\mathrm{C}$ and a soil factor $S=1.5$. The ductility reduction factor $R$, is taken $R=1$ considering that the vertical loads and the total base shear force are totally resisted by the non-ductile frame structure. The beams dimensions and reinforcement are shown in (Table 14) Figure 24. The column dimensions and reinforcement details are shown in Table 15. (Table 16), (Table 6) show the footing and tie beams dimensions.

\subsubsection{Design Results}

1) Construction bill of quantities for the designed structure

The cost of the structural works needed for construction is shown in Table 21.

2) Performance based analysis for the designed structure

The performance based analysis is performed by nonlinear static pushover analysis that is implemented using the SAP2000 software (Computer and Structures 2014). The force on each floor used for pushover analysis is shown in Table 14.

\subsubsection{Capacity Curve}

The load-displacement capacity curve resulted is shown in Figure 22.

\subsubsection{Plastic Hinge Mechanism}

At each pushover analysis step obtain the location of hinges in the structural elements, plastic hinges rotation and hinges reached to the FEMA provisions, which are IO, LS, and CP identified by using colored plastic hinges as shown in Figure 23. The building elevations are numbered as shown in Figure 10. 


\subsubsection{Plastic Moment at Collapse in (ton·m)}

For columns at step 5 as shown in Figure 24.

For beams at step 5 as shown in Figure 25.

Axial force in (t) for columns at step 5 as shown in Figure 26.

\subsubsection{Crack Width Value for Beams and Columns after the Earthquake Occurrence in ( $\mathrm{mm})$}

By using equations of the (ECP-203) [9] code, the crack width values for beams and columns are shown in Figure 27.

Red color means that the steel element is yielded Green color means that the steel is not yielded.

By using the ECP-203 code [9] equations we can calculate the:

- Spacing between cracks in beams for calculation of the length of cracks needed to be injected with epoxy $=37 \mathrm{~cm}$.

By using an excel sheet that constructed for calculation of section's moment capacity:

- Moment capacity for beam B1= $41.69 \mathrm{t} \cdot \mathrm{m}$ and for beam B2 $=62.31 \mathrm{t} \cdot \mathrm{m}$.

- Neutral axis height for calculation of the length of cracks needed to be injected by epoxy $=63 \mathrm{~cm}$.

Table 14. Beams dimensions and reinforcement.

\begin{tabular}{|c|c|c|c|c|c|c|c|c|c|c|}
\hline \multirow{2}{*}{$\begin{array}{l}\text { BEAM } \\
\text { MARK }\end{array}$} & \multirow{2}{*}{$\begin{array}{c}\text { SIZE } \\
(\mathrm{BXD})\end{array}$} & \multicolumn{3}{|c|}{$\begin{array}{c}\text { BOTTOM } \\
\text { REINFORCEMENT }\end{array}$} & \multicolumn{3}{|c|}{ TOP REINFORCEMENT } & \multicolumn{3}{|c|}{ LINKS } \\
\hline & & LEFT & $\begin{array}{l}\text { MID } \\
\text { SPAN }\end{array}$ & RIGHT & LEFT & $\begin{array}{l}\text { MID } \\
\text { SPAN }\end{array}$ & RIGHT & LEFT & $\begin{array}{l}\text { MID } \\
\text { SPAN }\end{array}$ & RIGHT \\
\hline B1 & $400 \times 900$ & $8 \mathrm{~T} 16$ & $8 \mathrm{~T} 16$ & $8 \mathrm{~T} 16$ & $10 \mathrm{~T} 16$ & $4 \mathrm{~T} 16$ & $10 \mathrm{~T} 16$ & $6 ø 10 / \mathrm{m}$ & $5 ø 10 / \mathrm{m}$ & $6 ø 10 / \mathrm{m}$ \\
\hline B2 & $400 \times 900$ & $12 \mathrm{~T} 18$ & $12 \mathrm{~T} 18$ & $12 \mathrm{~T} 18$ & $15 \mathrm{~T} 18$ & $5 \mathrm{~T} 18$ & $15 \mathrm{~T} 18$ & $8 ø 14 / \mathrm{m}$ & $8 ø 12 / \mathrm{m}$ & $8 ø 14 / \mathrm{m}$ \\
\hline
\end{tabular}

Table 15. Footing dimensions and reinforcement.

\begin{tabular}{|c|c|c|c|c|c|c|c|c|c|c|}
\hline \multicolumn{11}{|c|}{ SCHEDULE OF ISOLATED FOOTINGS } \\
\hline \multirow{2}{*}{$\begin{array}{l}\text { FOOTIN } \\
\text { G MARK }\end{array}$} & \multicolumn{3}{|c|}{$\begin{array}{l}\text { P.C. FOOTING } \\
\text { DIM.(mm) }\end{array}$} & \multicolumn{3}{|c|}{$\begin{array}{l}\text { R.C. FOOTING } \\
\text { DIM.(mm) }\end{array}$} & \multicolumn{2}{|c|}{$\begin{array}{c}\text { BOTTOM } \\
\text { REINFORCEMENT }\end{array}$} & \multicolumn{2}{|c|}{$\begin{array}{c}\text { TOP } \\
\text { REINFORCEMEN } \\
\mathrm{T}\end{array}$} \\
\hline & $\mathrm{B}$ & $\mathrm{L}$ & THICK. & $\mathrm{B}$ & $\mathrm{L}$ & THICK. & $\begin{array}{l}\text { SHORT } \\
\text { DIR. }\end{array}$ & $\begin{array}{l}\text { LONG } \\
\text { DIR. }\end{array}$ & $\begin{array}{l}\text { SHORT } \\
\text { DIR. }\end{array}$ & $\begin{array}{l}\text { LONG } \\
\text { DIR. }\end{array}$ \\
\hline $\mathrm{F} 1$ & 3000 & 3000 & 300 & 2400 & 2400 & 700 & $8 \mathrm{~T} 18 / \mathrm{m}$ & $8 \mathrm{~T} 18 / \mathrm{m}$ & --- & --- \\
\hline $\mathrm{F} 2$ & 3900 & 3900 & 300 & 3300 & 3300 & 700 & $9 \mathrm{~T} 18 / \mathrm{m}$ & $9 \mathrm{~T} 18 / \mathrm{m}$ & --- & --- \\
\hline F3 & 5200 & 5200 & 300 & 4600 & 4600 & 800 & $10 \mathrm{~T} 18 / \mathrm{m}$ & $10 \mathrm{~T} 18 / \mathrm{m}$ & --- & --- \\
\hline
\end{tabular}

Table 16. Cost of structural works.

\begin{tabular}{cccccc}
\hline Item & $\begin{array}{c}\text { Volume } \\
\left(\mathrm{m}^{3}\right)\end{array}$ & $\begin{array}{c}\text { Contractor } \\
\text { fees (Pounds) }\end{array}$ & $\begin{array}{c}\text { Material cost } \\
\text { (Pounds) }\end{array}$ & $\begin{array}{c}\text { Supervision } \\
\text { percentage (\%) }\end{array}$ & $\begin{array}{c}\text { Losses } \\
\text { percentage (\%) }\end{array}$ \\
\hline Plain Concrete & 37.64 & 130 & 690 & 10 & 3 \\
Reinforced Concrete & 463.6 & 330 & 690 & 10 & 3 \\
\hline
\end{tabular}

Total construction cost $=1323868.4 \mathrm{~L} \cdot \mathrm{E}$, Total construction cost $/ \mathrm{m}^{2}$ of floor $=1313.37 \mathrm{~L} \cdot \mathrm{E} / \mathrm{m}^{2}$. 


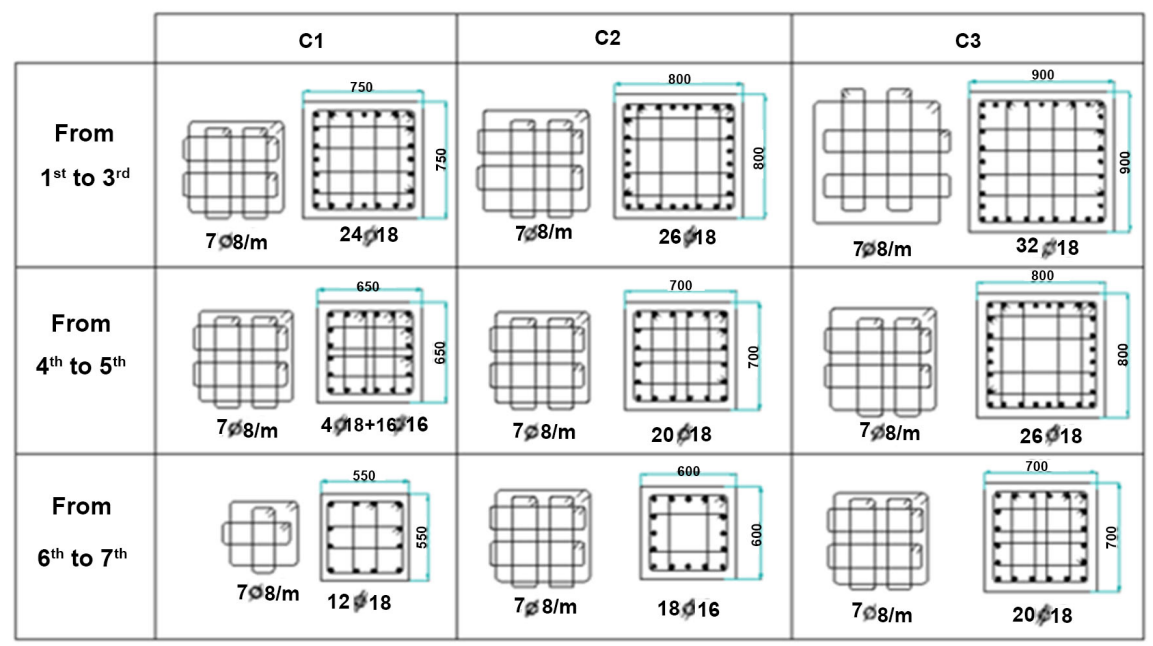

Figure 21. Columns dimensions and reinforcement.

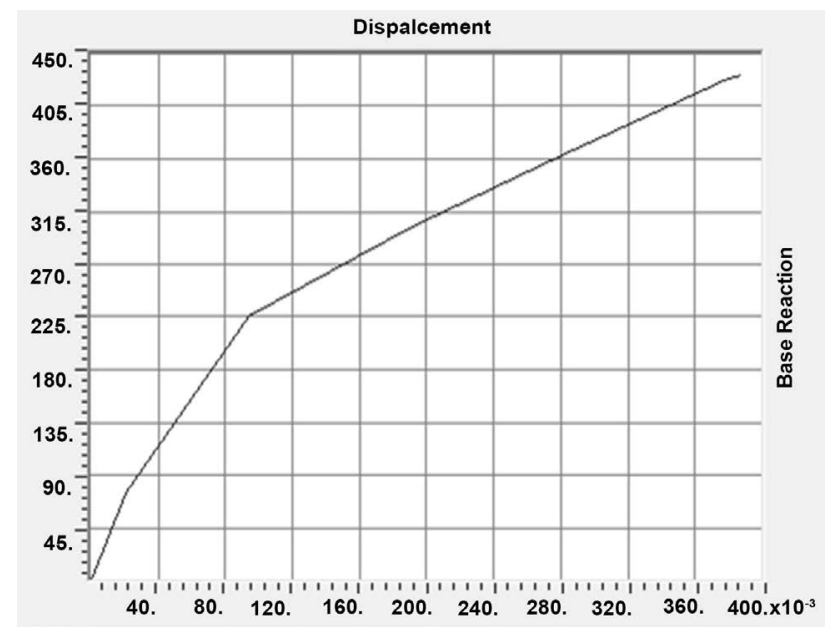

Figure 22. Pushover Curve for the Building in $\mathrm{x}, \mathrm{y}$ Directions.

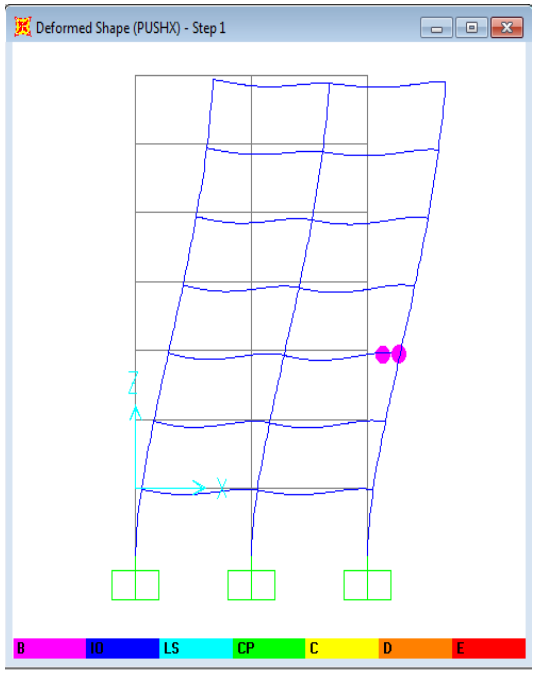

(a)

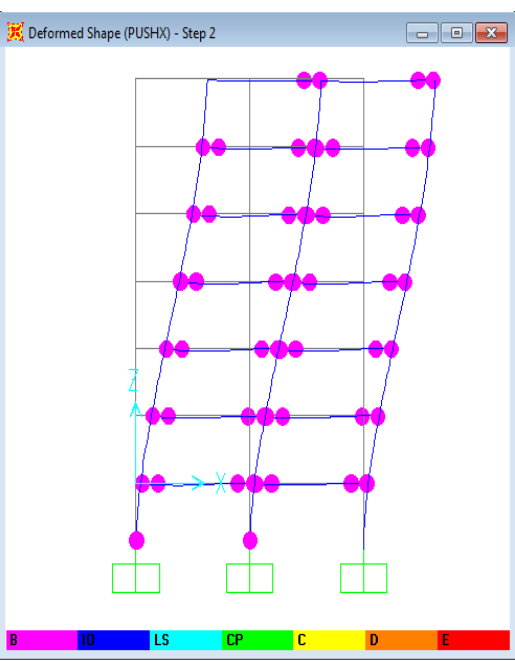

(b) 


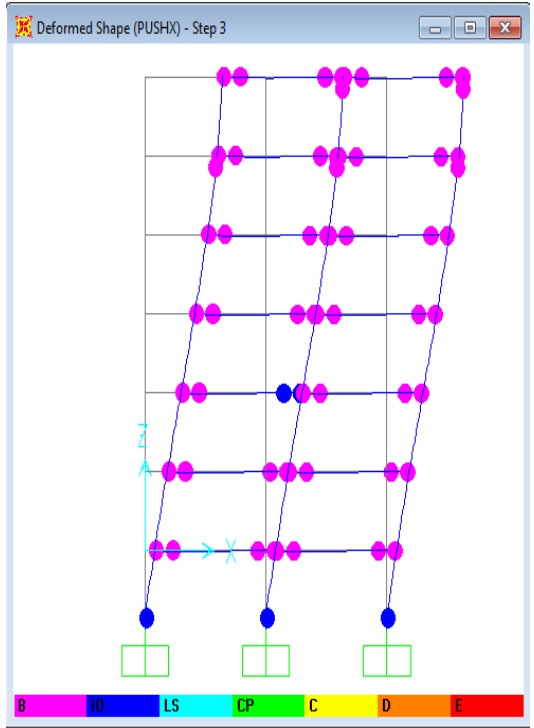

(c)

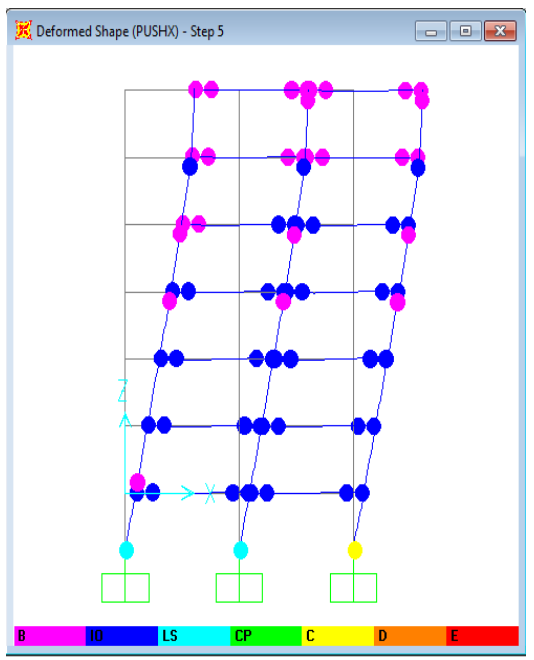

(e)

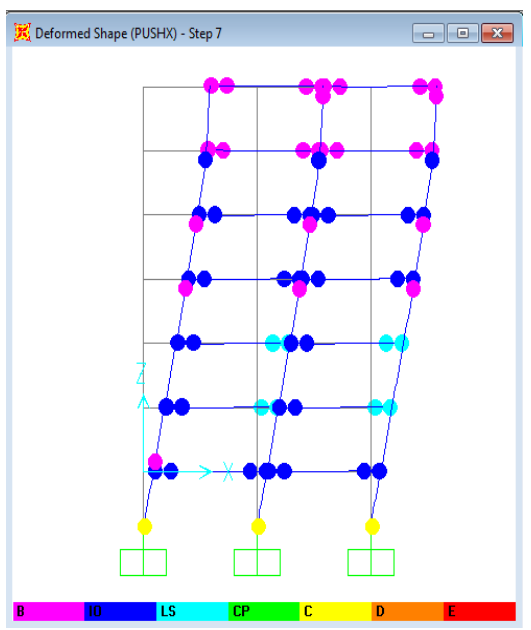

(g)

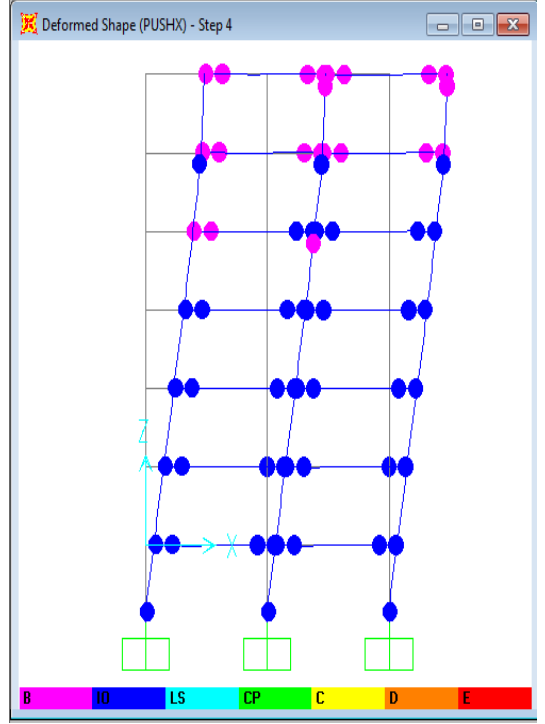

(d)

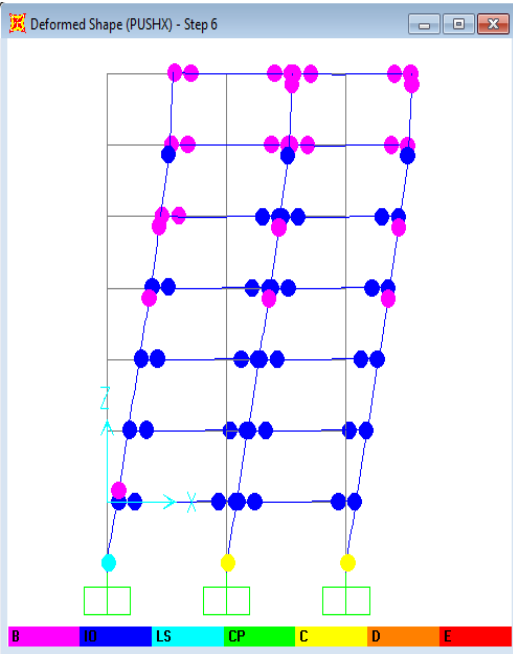

(f)

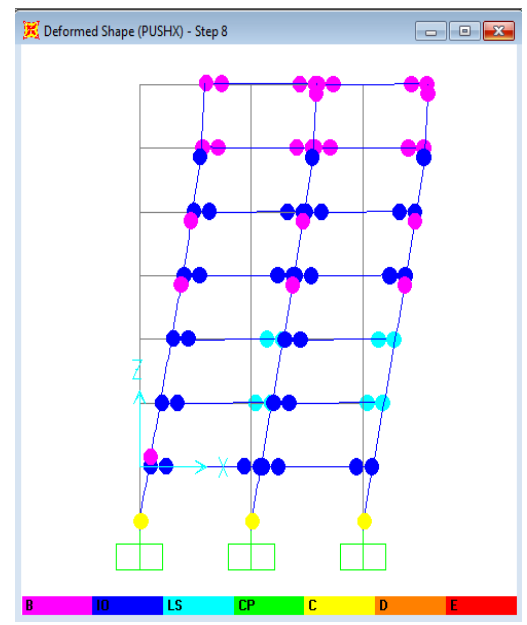

(h) 


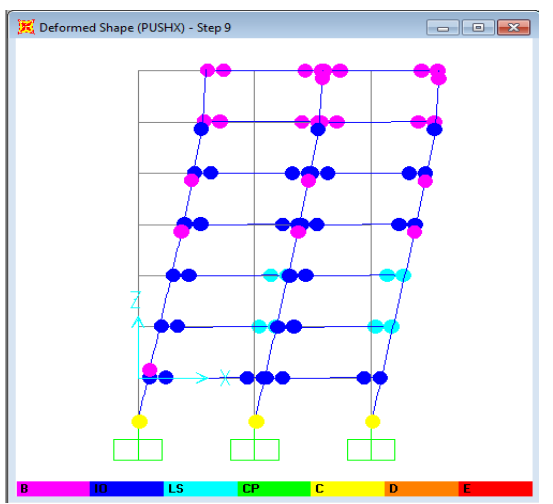

(i)

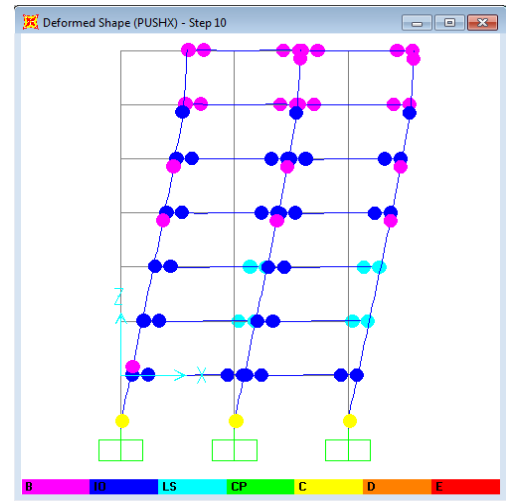

(j)

Figure 23. (a) Plastic hinge pattern at step 1 (Elevation 3); (b) Plastic hinge pattern at step 2 (Elevation 2); (c) Plastic hinge pattern at step 3 (Elevation 2); (d) Plastic hinge pattern at step 4 (Elevation 3); (e) Plastic hinge pattern At step 5 ( Elevation 3) (f) Plastic hinge pattern at step 6 (Elevation 3); (g) Plastic hinge pattern at step 7 (Elevation 3); (h) Plastic hinge pattern at step 8(Elevation 3); (i) Plastic hinge pattern at step 9 (Elevation 3); (j) Plastic hinge pattern at step 10 (Elevation 3); (k) Plastic hinge pattern at step 11 (Elevation 3); at step 12 (Elevation 3).

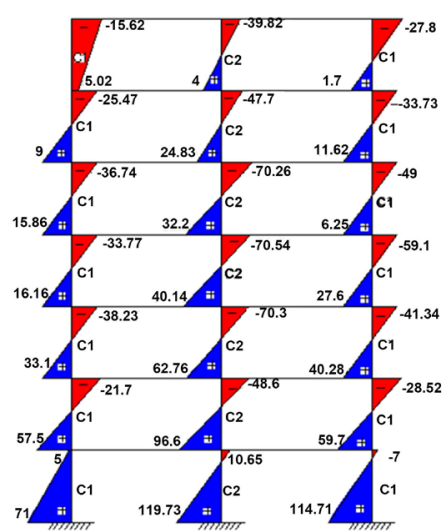

(a)

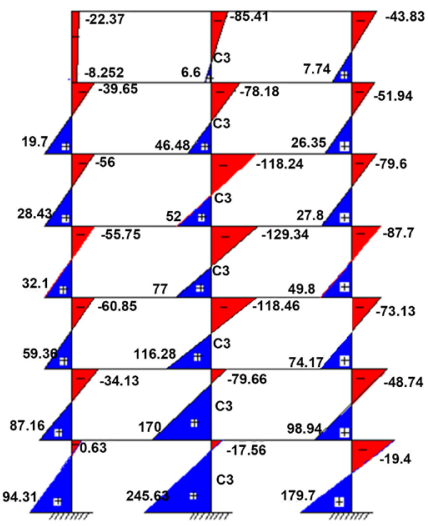

(b)

Figure 24. (a) Moment at elevations 1 \& 3; (b) Moment at elevation 2.

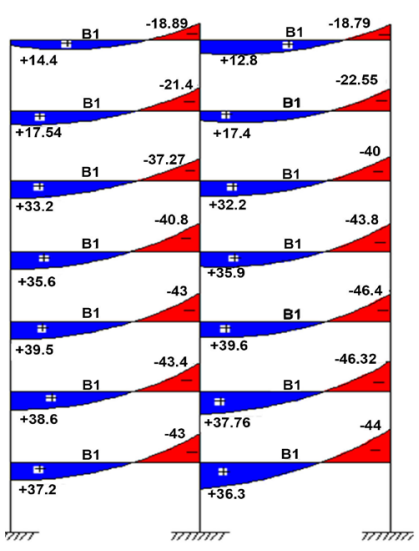

(a)

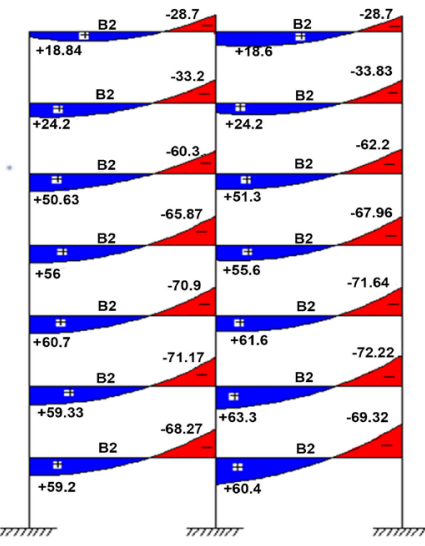

(b)

Figure 25. (a)Moment at elevations 1 \& 3; (b) Moment at elevation 2. 


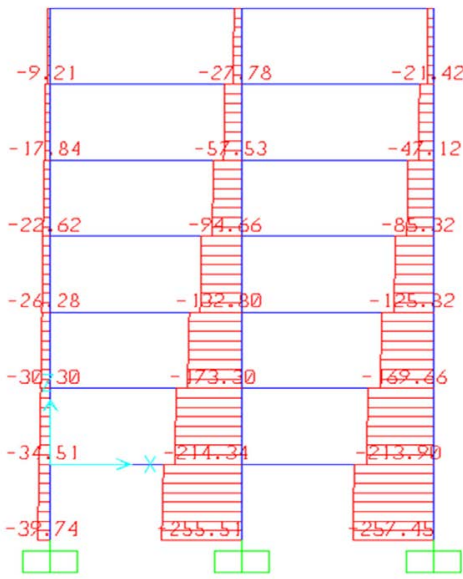

(a)

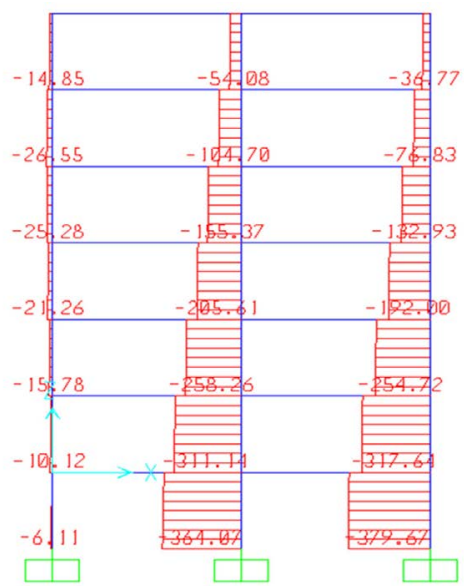

(b)

Figure 26. (a) Axial force at elevations 1 \& 3; (b) Axial force at elevation 2.

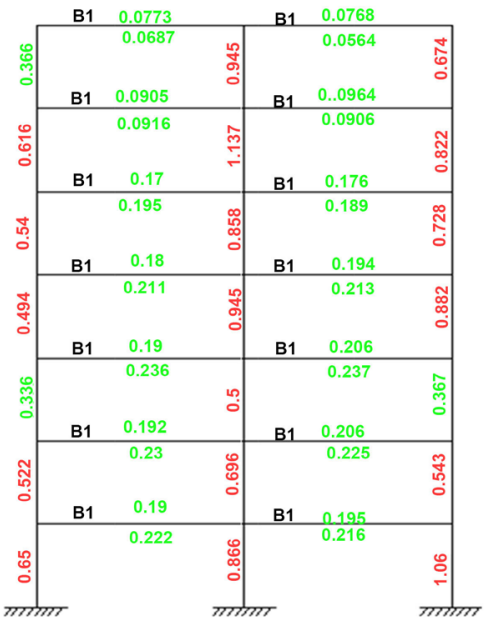

(a)

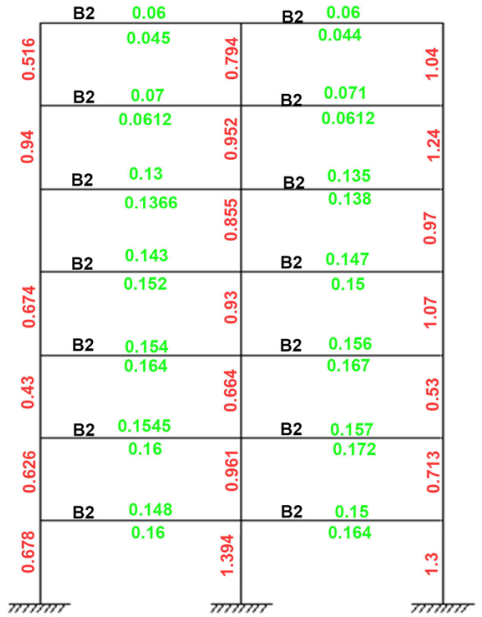

(b)

Figure 27. (a) Crack width at elevations $1 \& 3$; (b) Crack width at elevation 2.

\subsection{Case Study (4)}

The prototype concrete building designed to sustain vertical loads and linear static seismic loads determined from the regulations of the Egyptian Society for Earthquake Engineering (ESEE).

Earthquake loads according to the Egyptian Society for Earthquake Engineering (ESEE) Regulations.

A residential building located in Cairo, Egypt, the floor height $=3 \mathrm{~m}$, floors number $=7$.

Total horizontal seismic force $(V)=C_{s} \times W_{\text {total }}, C_{s}=$ ZISMRQ

Importance factor $(I)=1$

Structural system type factor $(S)=1$

Material factor $(M)=1$

Risk factor $(R)=1$

Quality control factor $(Q)=1$ for Residential Building for Moment-Resisting Frames for Reinforced Concrete for No Risk for Good Quality Control 
The seismic zoning factor $(Z)=A C F$

Horizontal acceleration ratio $(A)=0.04 \mathrm{~g}$ for Cairo, Egypt

Foundation soil factor $(F)=1.3 \quad$ for fine grained soil

$$
\text { Time period }(T)=\frac{0.09 H}{\sqrt{d}}=\frac{0.09 \times 21}{\sqrt{12}}=0.5456 \text { second }
$$

Coefficient of standardized response spectrum for average damping of $5 \%(C)$ $=0.89$.

According to the value of $(\mathrm{T})$ determined from Figure 22 [2].

$\mathrm{Z}=0.04 \times 0.89 \times 1.3=0.0463, \mathrm{C}_{\mathrm{s}}=\mathrm{Z}$ I S M R Q $=0.0463 \times 1 \times 1 \times 1 \times 1 \times 1=$ 0.0463 .

\section{Calculation of weight for all floors}

$$
\begin{aligned}
& W_{\text {slab+beams }}=1.04 \times 12 \times 12 \times 7=1048.32 \mathrm{t}, \\
& W_{\text {columns }}=[(4 \times 0.4 \times 0.4)+(4 \times 0.5 \times 0.5)+(0.7 \times 0.7)] \times 2.5 \times 21=111.825 \mathrm{t}, \\
& W_{\text {dead }}=1048.32+111.825=1160.145 \mathrm{t}, \quad W_{\text {live }}=0.2 \times 12 \times 12 \times 7=201.6 \mathrm{t}, \\
& W_{\text {total }}=W_{D}+0.25 W_{L}=1210.55 \mathrm{t}, W_{\text {floor }}=172.94 \mathrm{t}
\end{aligned}
$$

Calculation of total base shear force and the horizontal force on each floor (Table 17).

$$
\begin{aligned}
& V=C_{s} \times W_{\text {total }}=0.0463 \times 1210.55=56 \mathrm{t}, \\
& \sum W_{i} h_{i}=172.94(3+6+9+12+15+18+21)=14526.96 \mathrm{t} \cdot \mathrm{m} \\
& F_{i}=\left[\frac{h_{i} \times W_{i}}{\sum_{j=1}^{n} h_{j} \times W_{j}}\right] \times V=56 \times\left[\frac{h_{i} \times 172.94}{14526.96}\right]=0.667 h_{i}
\end{aligned}
$$

\subsubsection{Design Results (Table 18, Figure 28, Table 19)}

1) Construction bill of quantities for the designed structure

The cost of the structural works needed for construction is shown in Table 20.

2) Performance based analysis for the designed structure

The performance based analysis is performed by nonlinear static pushover analysis that is implemented using the SAP2000 software (Computer and Structures 2014) [10]. The force on each floor used for pushover analysis is shown in Figure 28.

\subsubsection{Capacity Curve}

The load-displacement capacity curve resulted is shown in Figure 29.

\subsubsection{Plastic Hinge Mechanism}

At each pushover analysis step obtain the location of hinges in the structural elements, plastic hinges rotation and hinges reached to the FEMA provisions, which are IO, LS, and CP identified by using colored plastic hinges as shown in Figure 30. The building elevations are numbered as shown in Figure 10.

\subsubsection{Plastic Moment at Collapse in (ton $\cdot \mathrm{m}$ )}

For columns at step 5 as shown in Figure 31. 
For beams at step 5 as shown in Figure 32.

Axial force in $(\mathrm{t})$ for columns at step 5 as shown in Figure 33.

\subsubsection{Crack Width Value for Beams and Columns after the Earthquake Occurrence in ( $\mathrm{mm})$}

By using equations of the (ECP-203) [9] code, the crack width values for beams and columns are shown in Figure 34.

Red color means that the steel is yielded Green color means that the steel is not yielded.

By using the ECP-203 [9] code equations we can calculate the:

- Spacing between cracks in beams for calculation of the length of cracks needed to be injected with epoxy $=18 \mathrm{~cm}$.

By using an excel sheet that constructed for calculation of section's moment capacity:

- Moment capacity for beam B1 $=10.1 \mathrm{t} \cdot \mathrm{m}$ and for beam B2 $=26.6 \mathrm{t} \cdot \mathrm{m}$.

- Average Neutral axis height for calculation of the length of cracks needed to be injected by epoxy $=32 \mathrm{~cm}$.

Table 17. The force on each floor, shear force and overturning moment.

\begin{tabular}{ccccc}
\hline Floor & hi $(\mathrm{m})$ & Fi (t) & Shear $(\mathrm{t})$ & Moment $(\mathrm{t} \cdot \mathrm{m})=\mathrm{hi} \times \mathrm{Fi}$ \\
\hline 7 & 21 & 14 & 14 & 294 \\
6 & 18 & 12 & 26 & 216 \\
5 & 15 & 10 & 36 & 150 \\
4 & 12 & 8 & 44 & 96 \\
3 & 9 & 6 & 50 & 54 \\
2 & 6 & 4 & 54 & 24 \\
1 & 3 & 2 & 56 & 6 \\
\hline
\end{tabular}

Table 18. Beams dimensions and reinforcement.

\begin{tabular}{|c|c|c|c|c|c|c|c|c|c|c|}
\hline \multirow{2}{*}{$\begin{array}{l}\text { BEAM } \\
\text { MARK }\end{array}$} & \multirow{2}{*}{$\begin{array}{c}\text { SIZE } \\
(\mathrm{BXD})\end{array}$} & \multicolumn{3}{|c|}{$\begin{array}{c}\text { BOTTOM } \\
\text { REINFORCEMENT }\end{array}$} & \multicolumn{3}{|c|}{$\begin{array}{c}\text { TOP } \\
\text { REINFORCEMENT }\end{array}$} & \multicolumn{3}{|c|}{ LINKS } \\
\hline & & LEFT & $\begin{array}{l}\text { MID } \\
\text { SPAN }\end{array}$ & RIGHT & LEFT & $\begin{array}{l}\text { MID } \\
\text { SPAN }\end{array}$ & RIGHT & LEFT & $\begin{array}{l}\text { MID } \\
\text { SPAN }\end{array}$ & RIGHT \\
\hline B1 & $250 \times 600$ & $3 \mathrm{~T} 16$ & $3 \mathrm{~T} 16$ & $3 \mathrm{~T} 16$ & $5 \mathrm{~T} 16$ & 3T12 & $5 \mathrm{~T} 16$ & $5 ø 8 / \mathrm{m}$ & $5 ø 8 / \mathrm{m}$ & $5 ø 8 / \mathrm{m}$ \\
\hline B2 & $250 \times 600$ & $5 \mathrm{~T} 16$ & $5 \mathrm{~T} 16$ & $5 \mathrm{~T} 16$ & $8 \mathrm{~T} 18$ & $4 \mathrm{~T} 16$ & $8 \mathrm{~T} 18$ & $8 ø 12 / \mathrm{m}$ & $8 ø 8 / \mathrm{m}$ & $8 ø 12 / \mathrm{m}$ \\
\hline
\end{tabular}

Table 19. Footing dimensions and reinforcement.

\begin{tabular}{|c|c|c|c|c|c|c|c|c|c|c|}
\hline \multicolumn{11}{|c|}{ SCHEDULE OF ISOLATED FOOTINGS } \\
\hline \multirow{3}{*}{$\begin{array}{l}\text { FOOTIN } \\
\text { G MARK }\end{array}$} & \multirow{2}{*}{\multicolumn{3}{|c|}{$\begin{array}{l}\text { P.C. FOOTING } \\
\text { DIM.(mm) }\end{array}$}} & \multirow{2}{*}{\multicolumn{3}{|c|}{$\begin{array}{l}\text { R.C. FOOTING } \\
\text { DIM.(mm) }\end{array}$}} & \multirow{2}{*}{\multicolumn{2}{|c|}{$\begin{array}{c}\text { BOTTOM } \\
\text { REINFORCEMENT }\end{array}$}} & \multicolumn{2}{|c|}{ TOP } \\
\hline & & & & & & & & & REINFO & EMENT \\
\hline & B & $\mathrm{L}$ & THICK. & $\mathrm{B}$ & $\mathrm{L}$ & $\begin{array}{l}\text { THIC } \\
\text { K. }\end{array}$ & $\begin{array}{l}\text { SHORT } \\
\text { DIR. }\end{array}$ & $\begin{array}{l}\text { LONG } \\
\text { DIR. }\end{array}$ & $\begin{array}{l}\text { SHORT } \\
\text { DIR. }\end{array}$ & $\begin{array}{l}\text { LONG } \\
\text { DIR. }\end{array}$ \\
\hline $\mathrm{F} 1$ & 2800 & 2800 & 300 & 2200 & 2200 & 700 & 7T16/m & $7 \mathrm{~T} 16 / \mathrm{m}$ & --- & --- \\
\hline $\mathrm{F} 2$ & 3700 & 3700 & 300 & 3100 & 3100 & 700 & $9 \mathrm{~T} 16 / \mathrm{m}$ & $9 \mathrm{~T} 16 / \mathrm{m}$ & --- & --- \\
\hline F3 & 5000 & 5000 & 300 & 4400 & 4400 & 800 & $10 \mathrm{~T} 18 / \mathrm{m}$ & $10 \mathrm{~T} 18 / \mathrm{m}$ & --- & --- \\
\hline
\end{tabular}


Table 20. Cost of structural works.

\begin{tabular}{cccccc}
\hline Item & $\begin{array}{c}\text { Volume } \\
\left(\mathrm{m}^{3}\right)\end{array}$ & $\begin{array}{c}\text { Contractor fees } \\
\text { (Pounds) }\end{array}$ & $\begin{array}{c}\text { Material cost } \\
\text { (Pounds) }\end{array}$ & $\begin{array}{c}\text { Supervision } \\
\text { percentage (\%) }\end{array}$ & $\begin{array}{c}\text { Losses percentage } \\
(\%)\end{array}$ \\
\hline Plain Concrete & 33.34 & 130 & 690 & 10 & 3 \\
Reinforced Concrete & 329.05 & 330 & 690 & 10 & 3 \\
\hline
\end{tabular}

Total construction cost $=996450 \mathrm{~L} \cdot \mathrm{E}$, Total construction cost $/ \mathrm{m}^{2}$ of floor $=988.55 \mathrm{~L} \cdot \mathrm{E} / \mathrm{m}^{2}$.

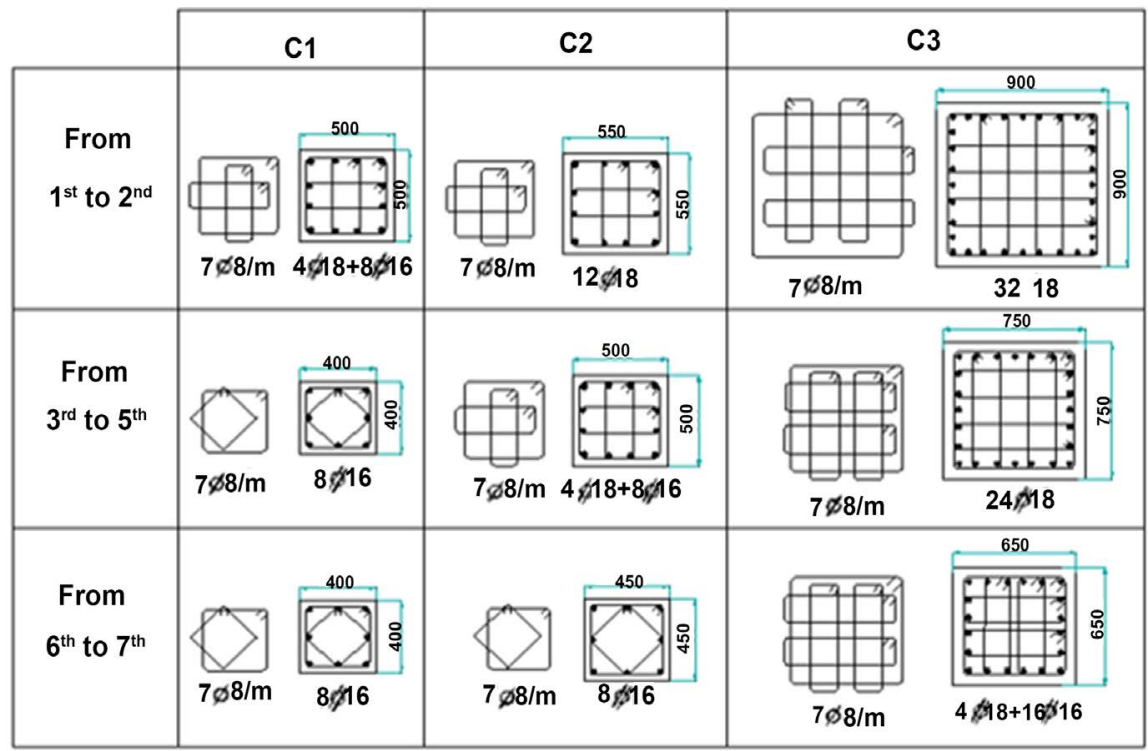

Figure 28. Columns dimensions and reinforcement.

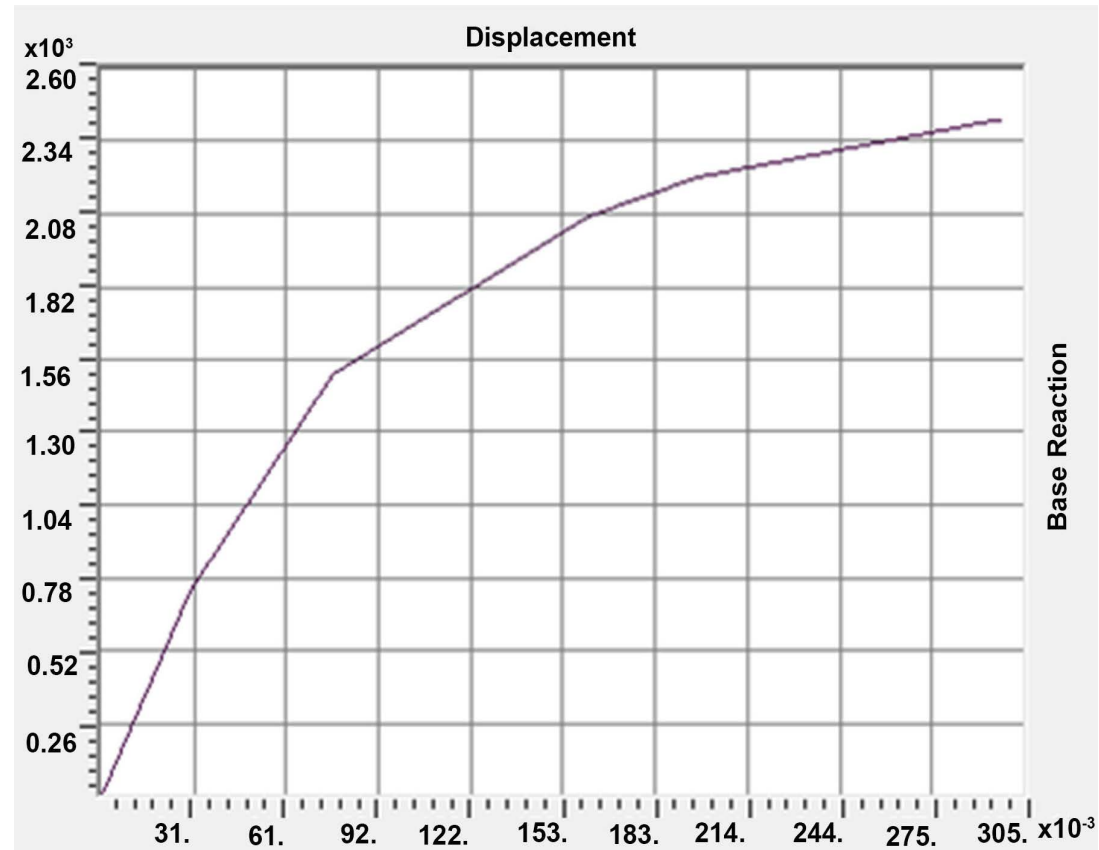

Figure 29. Pushover curve for the building in $\mathrm{x}, \mathrm{y}$ directions. 


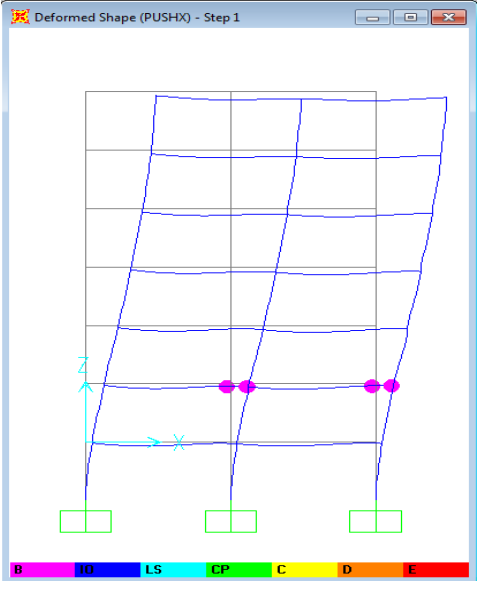

(a)

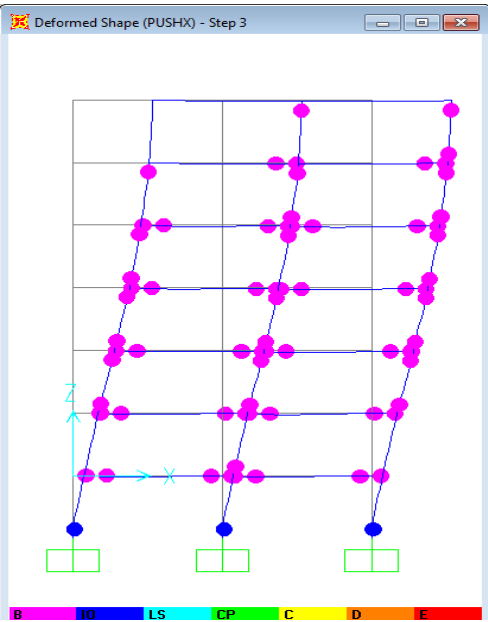

(c)

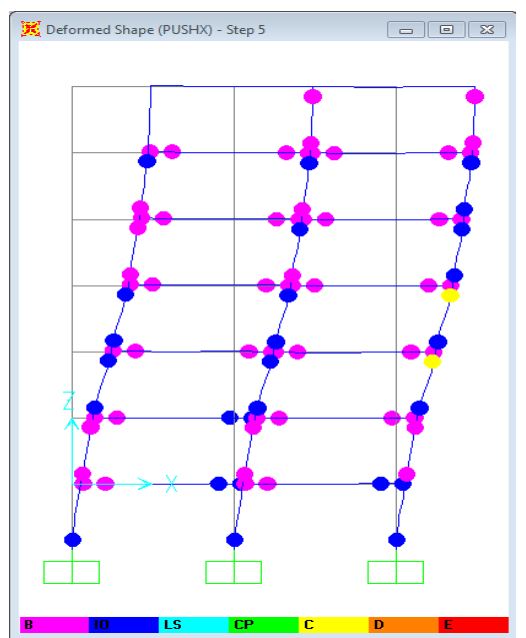

(e)

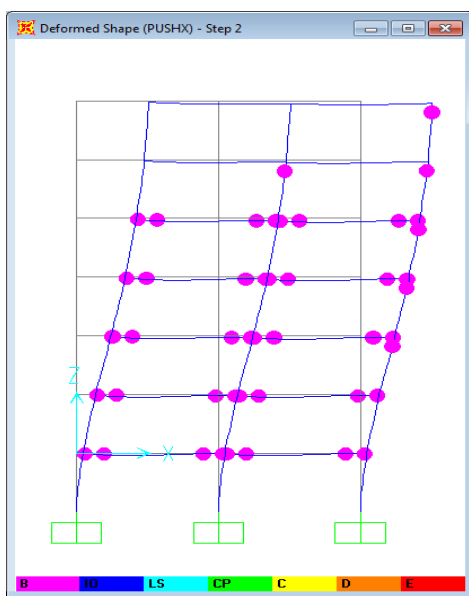

(b)

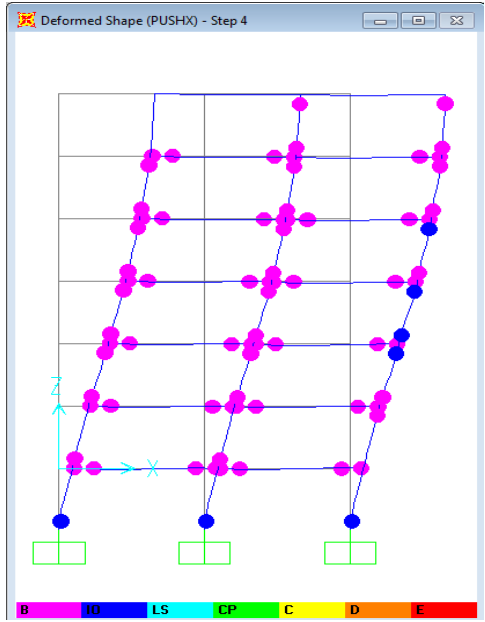

(d)

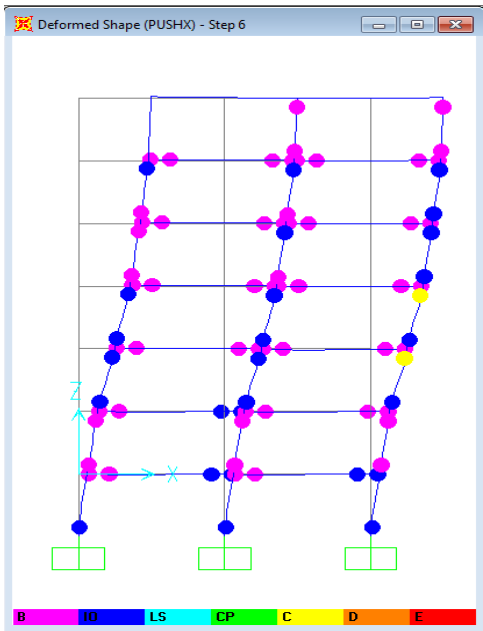

(f)

Figure 30. (a) Plastic hinge pattern at step 1 (Elevation 3); (b) Plastic hinge pattern at step 2 (Elevation 2); (c) Plastic hinge pattern at step 3 (Elevation 2); (d) Plastic hinge pattern at step 4 (Elevation 3); (e) Plastic hinge pattern for at step 5 (Elevation 3); (f) Plastic hinge pattern at step 6 (Elevation 3 ). 


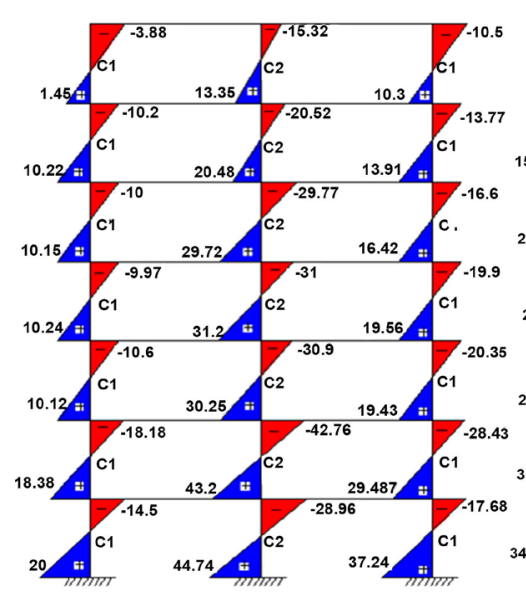

(a)

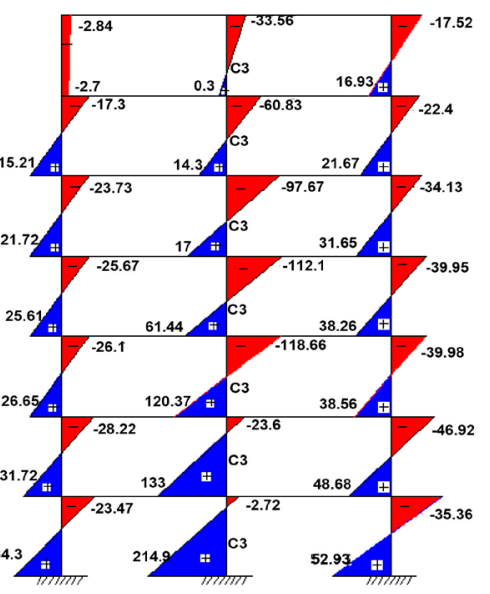

(b)

Figure 31. (a) Moment at elevations $1 \& 3$; (b) Moment at elevation 2.

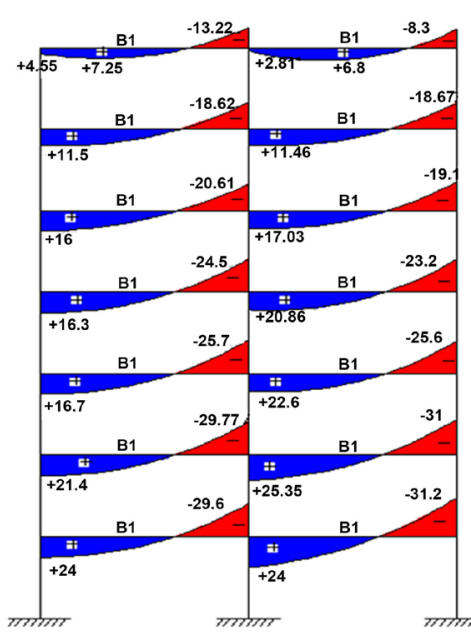

(a)

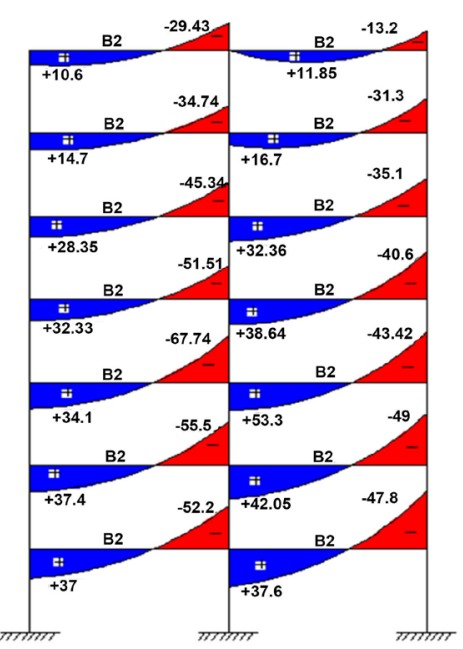

(b)

Figure 32. (a) Moment at elevations 1 \& 3; (b) Moment at elevation 2.

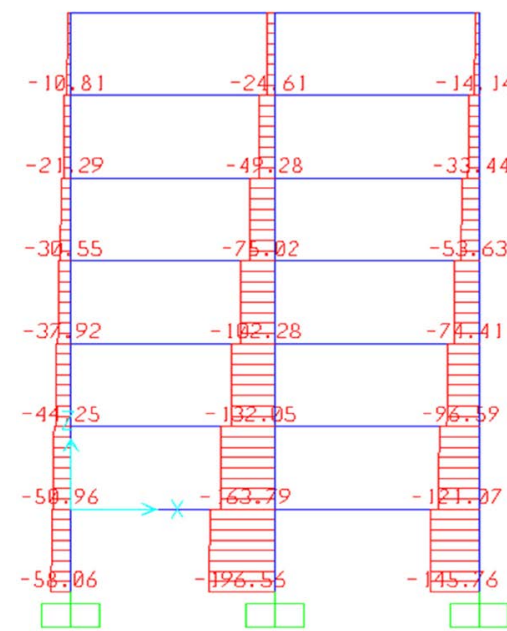

(a)

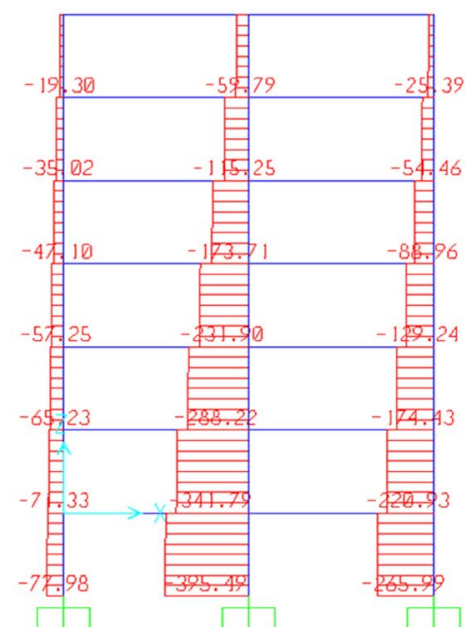

(b)

Figure 33. (a) Axial force at elevations $1 \& 3$; (b) Axial force at elevation 2. 


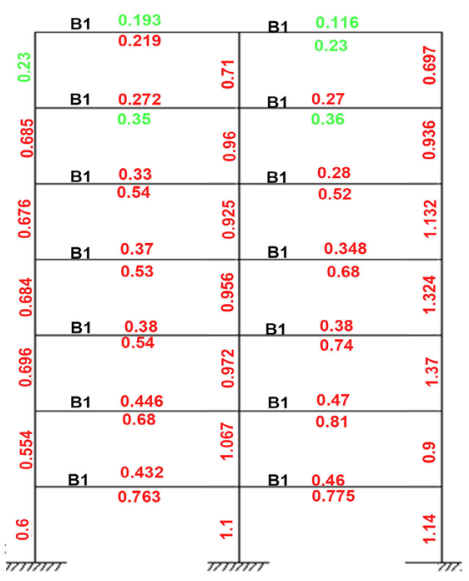

(a)

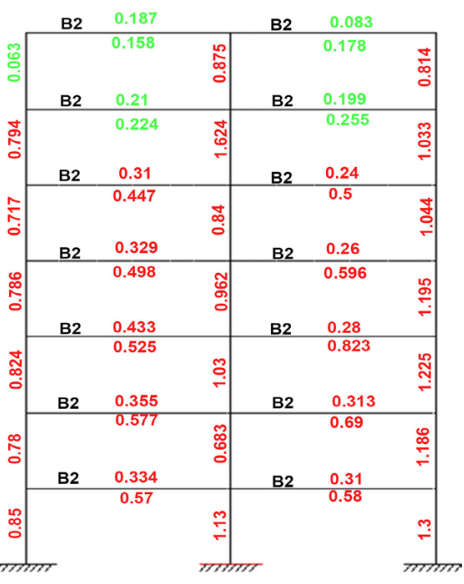

(b)

Figure 34. (a) Crack width at elevations $1 \& 3$; (b) Crack width at elevation 2.

\subsection{Levels of Damage and the Repairing Techniques of the Structure}

Repairing of the structure after an earthquake event is determined mainly by its level of damage that determined by the width of cracks in concrete members and the reinforcing steel bars condition (yielded or not). We can detect the damage levels and the most appropriate repairing technique as mentioned below in Figure 35 .

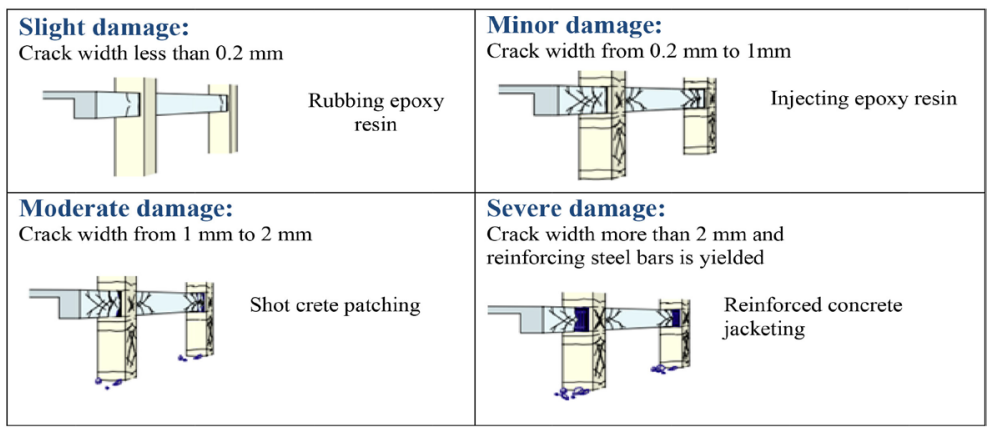

Figure 35. Damage levels, according to the crack width and its repairing techniques (Sugimoto 2004) [11].

\section{Results and Discussion}

The cost assessment results are summarized in Table 21, and Figure 36.

Table 21. Assessment results for each design case.

\begin{tabular}{lccccc}
\hline Design Case & $\begin{array}{c}\text { Construction cost } \\
\left(\mathrm{L} \cdot \mathrm{E} / \mathrm{m}^{2}\right)\end{array}$ & $\begin{array}{c}\text { Repair cost } \\
\left(\mathrm{L} \cdot \mathrm{E} / \mathrm{m}^{2}\right)\end{array}$ & $\begin{array}{c}\text { Base Shear }(\mathrm{t}) \\
\text { Resistance }\end{array}$ & $\begin{array}{c}\text { Life cycle cost } \\
\left(\mathrm{L} \cdot \mathrm{E} / \mathrm{m}^{2}\right)\end{array}$ & $\begin{array}{c}\text { Construction } \\
\text { Cost Ratio }\end{array}$ \\
\hline Case 1 (D+ L) & 883.46 & 426.6 & 184.87 & 1310.05 & $\begin{array}{c}1 \\
(\text { The reference } \\
\text { value })\end{array}$ \\
Case 2 (R = 5) & 950.14 & 391.87 & 246.25 & 1342 & 1.0755 \\
Case 3 (R $=1)$ & 1313.37 & 277.8 & 431.29 & 1591.14 & 1.487 \\
Case 4 (ESEE) & 988.55 & 377 & 246.58 & 1356.53 & 1.12 \\
\hline
\end{tabular}




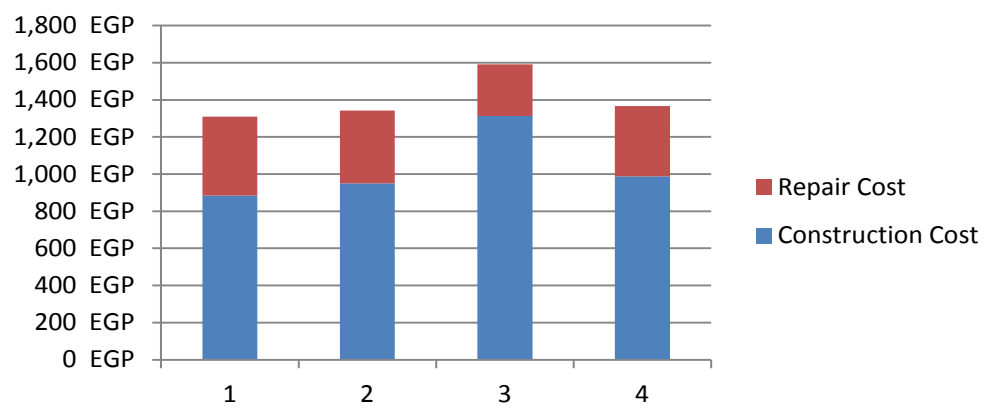

Figure 36. Repair cost and construction cost for each design case.

\section{Conclusions}

The nonlinear analysis of structures designed to resist earthquakes is very important to assess the response of the structure under earthquake effect and to know the state of the building after seismic load. The ductility of building is very important but one should be careful since the large displacement will be accompanied with damage that can make the structural members irreparable and the building may lose its function. One should perform a cost assessment for each seismic mitigation design to visualize the life cycle cost of the structure to get a cost effective design, which consists of the construction cost and the repairing cost after earthquake damage. The paper presented a proposed method for seismic performance evaluation for existing and new structures depending on the width of cracks resulted from the seismic exposure. Also it helps engineers to perform a cost assessment for the reinforced concrete buildings designed to resist earthquakes to get its life cycle cost.

The steps and methodology required for structural evaluation and cost assessment mentioned in this study are summarized as follows:

1) Construct a 3-D model for structure to be analyzed by using sap 2000 software.

2) Calculate the construction cost of the designed structure by $\left(\mathrm{L} \cdot \mathrm{E} / \mathrm{m}^{2}\right)$ as shown in Table 22.

3) Perform a nonlinear static pushover analysis by using SAP2000 software to locate the weakness points in the structure that appears as cracks in the structural members, if this structure is constructed and exposed to the designed seismic ground acceleration and story shear as shown in Table 23; anticipate the structure capability to undergo the deformations beyond the elastic zone determines the structural behavior of the building during seismic hazard as shown in Figure 37 , and then determine the location of the plastic hinges in columns and beams as shown in Figure 38.

4) Get the plastic moment on each member as shown in Figure 39 that undergoes beyond the elastic behavior to the yielding behavior, and calculate the crack width in the structure according to its plastic moment as shown in Figure 40 . 
Table 22. Construction cost for the building.

\begin{tabular}{cccccc}
\hline Item & $\begin{array}{c}\text { Volume } \\
\left(\mathrm{m}^{3}\right)\end{array}$ & $\begin{array}{c}\text { Contractor fees } \\
\text { (Pounds) }\end{array}$ & $\begin{array}{c}\text { Material cost } \\
\text { (Pounds) }\end{array}$ & $\begin{array}{c}\text { Supervision } \\
\text { percentage } \\
(\%)\end{array}$ & $\begin{array}{c}\text { Losses } \\
\text { percentage (\%) }\end{array}$ \\
\hline Plain Concrete (P.C) & $\ldots$ & $\ldots$ & $\ldots$ & $\ldots$. & $\ldots$ \\
Reinforced Concrete (R.C) & $\ldots$ & $\ldots$ & $\ldots$ & $\ldots$ & $\ldots$ \\
\hline
\end{tabular}

Cost of P.C $=$ volume $\times($ contractor fees + material cost $) \times \%$ of losses and Supervision cost; Cost of R.C $=$ volume $\times$ (contractor fees + material cost $) \times \%$ of losses and Supervision cost; Cost of Reinforcement $=$ steel weight $\times$ unit cost $\times \%$ of losses and Supervision cost.

Table 23. The EQ force on each floor.

\begin{tabular}{ccc}
\hline Floor & hi (m) & Fi (t) \\
\hline 7 & 21 & 11.571 \\
6 & 18 & 9.918 \\
5 & 15 & 8.265 \\
4 & 12 & 6.612 \\
3 & 9 & 4.959 \\
2 & 6 & 3.306 \\
1 & 3 & 1.653 \\
\hline
\end{tabular}

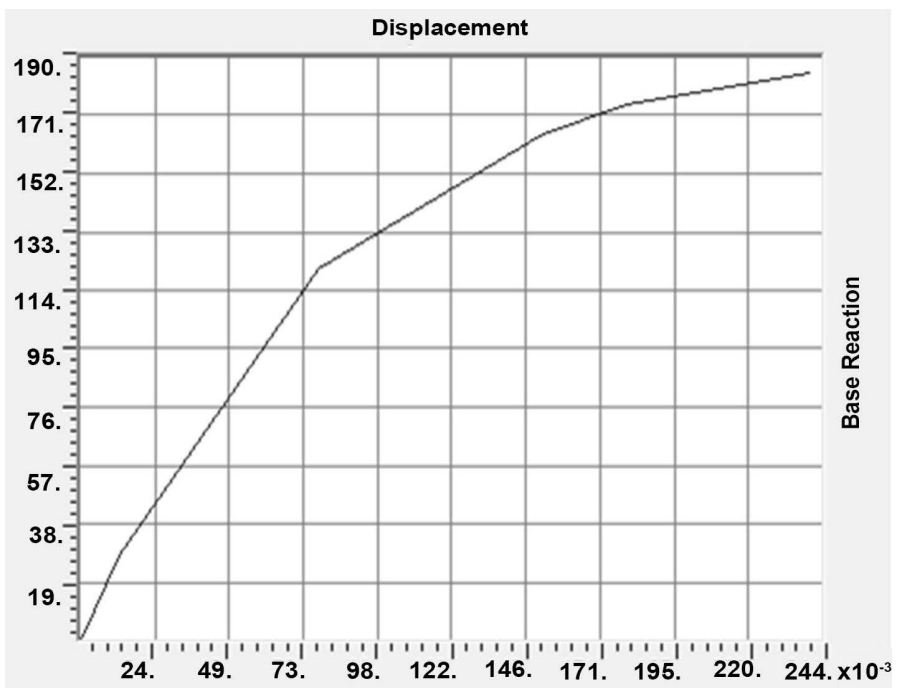

Figure 37. Pushover curve of the building $(\mathrm{t} \cdot \mathrm{m})$.

5) Select the suitable repairing method for each member according to the crack width value as shown in Table 23, stress in reinforcement steel bars, and the drift in the structure; then get the repairing cost for each member in the structure.

6) Calculate the repairing cost of the structure for each design approach by $\left(\mathrm{L} \cdot \mathrm{E} / \mathrm{m}^{2}\right)$ as shown in Table 24 [13]. 


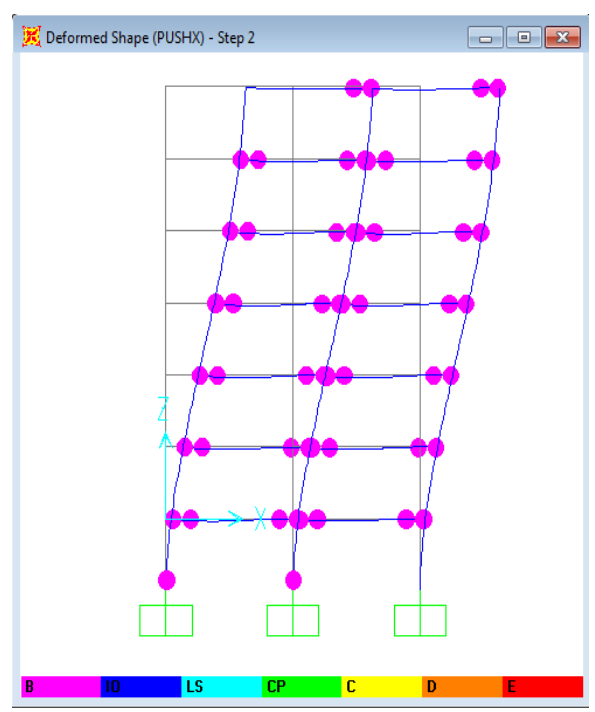

(a)

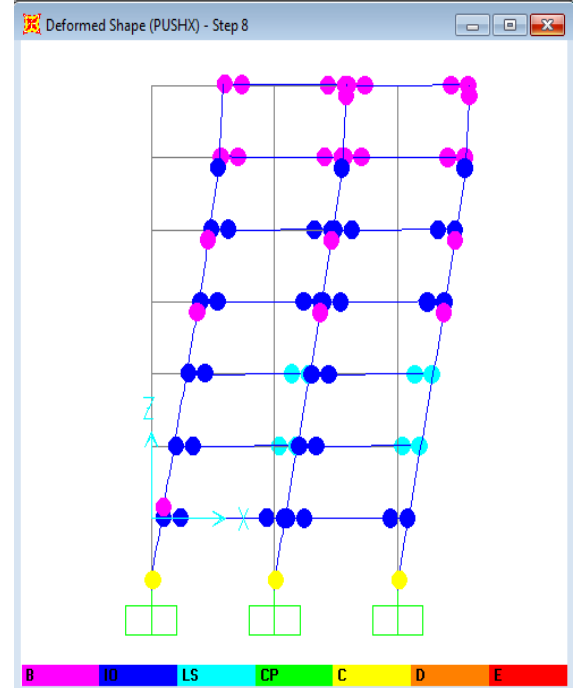

(b)

Figure 38. Plastic hinge pattern for building at a different performance level by SAP 2000 software.

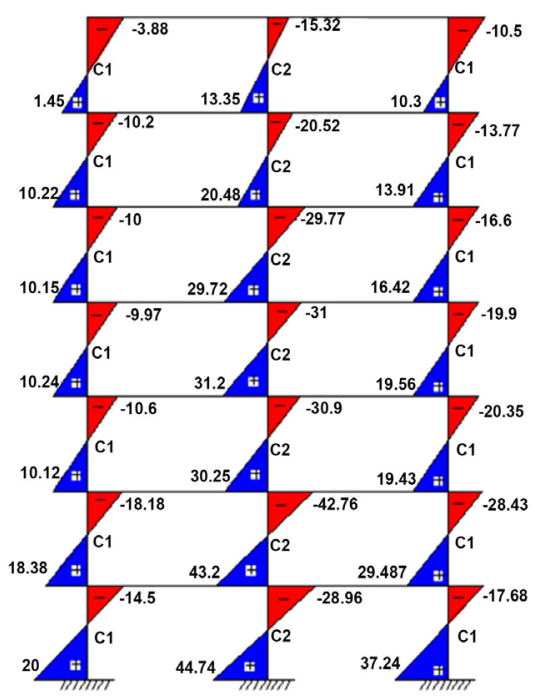

(a)

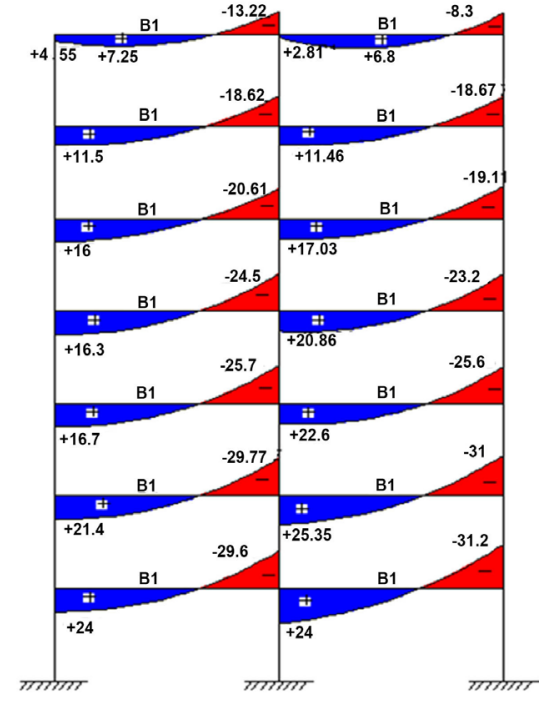

(b)

Figure 39. Plastic Moment for columns and beams.

Table 24. Repairing Cost according to damage level [8].

\begin{tabular}{ccc}
\hline Damage & Unit & Repair cost (L.E/unit) \\
Slight & $\mathrm{m}$ & 65 \\
Minor & $\mathrm{m}$ & 135 \\
Moderate & $\mathrm{m}^{2}$ & 430 \\
Severe & $\ldots$ & $2800+$ Steel bars cost
\end{tabular}




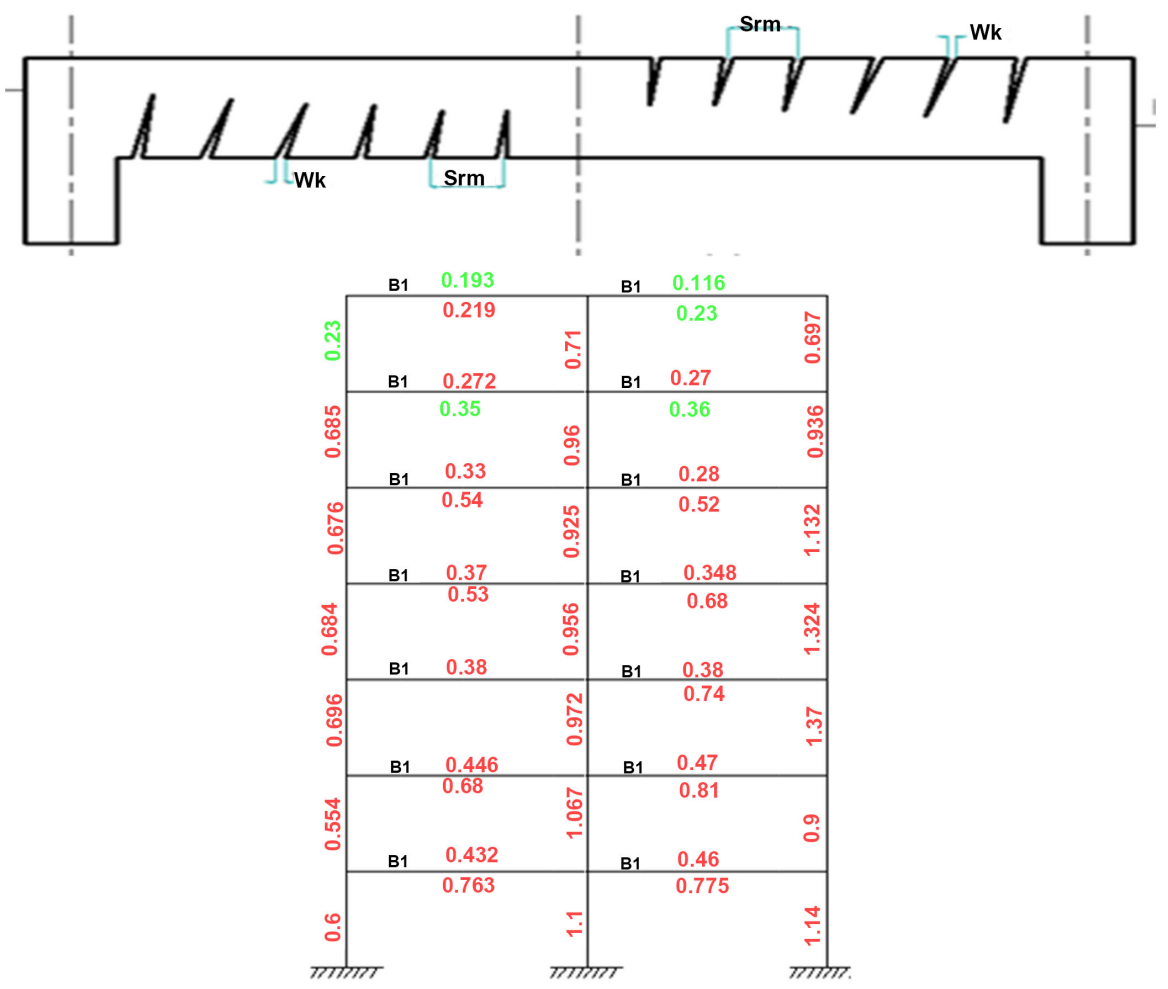

Figure 40. Crack width values $\left(\mathrm{W}_{\mathrm{k}}\right)$ for columns and beams.

7) Perform a cost analysis for assessment of the cost-efficiency of seismic mitigation design based on the long term performance of the structure subjected to seismic hazard, a life-cycle cost due to the initial construction cost should be included to assess the impact of potential earthquakes that occurred during the expected life-cycle of the structure. Generally, a more resistant design with higher initial construction cost will have a lower life-cycle cost.

\section{Conflicts of Interest}

The authors declare no conflict of interest, financial or otherwise.

\section{References}

[1] Krawinkler, H. and Seneviratna, G.D.P.K. (1998) Pros. and Cons. of a Pushover Analysis of Seismic Performance Evaluation. Engineering Structures, 20, 452-464.

[2] Maske, A.A., Maske, N.A. and Shiras, P.P. (2014) Pushover Analysis of Reinforced Concrete Frame Structures: A Case Study. Civil Engineering, Assistant Professor, Nagpur Institute of Technology, India.

[3] Bhagure, G.S. (2016) Analytical Study on Performance Evaluation of Multi-Story RC Building by Direct Displacement Approach. Department of Structural Engineering, Government College of Engineering, Aurangabad, India.

[4] Igarashi, S. and Maeda, M. (2012) Evaluation of Seismic Reparability Limit State of $\mathrm{R} / \mathrm{C}$ Frame Structure Based on the Damage of Columns and Beams. Proceedings of 15 th WCEE, Lisbon, Portugal. 
[5] ECP-201 (2012) Egyptian Code of Practice for Calculation of Loads and Forces in Structures and Buildings. National Housing and Building Research Center, Cairo.

[6] Egyptian Society of Earthquake Engineering (ESEE) (1988) Regulations for Earthquake-Resistance Design of Buildings in Egypt, Cairo.

[7] Hakim, R., Alama, M. and Ashour, S. (2014) Seismic Assessment of an RC Building Using Pushover Analysis building. King Abdul-Aziz University, Jeddah, Saudi Arabia.

[8] FEMA 356 (2000) Prestandard and Commentary for the Seismic Rehabilitation of Buildings. Federal Emergency Management Agency, Washington DC.

[9] ECP-203 (2007) Egyptian Code for Design and Construction of Reinforced Concrete Structures. National Housing and Building Research Center.

[10] Computers and Structures, Inc. (2014) SAP2000 Advanced 14.0.0. Static and Dynamic Finite Element Analysis of Structures. CSI, Berkeley, CA.

[11] Autodesk, Inc. (2014) Autocad, 2D and 3D Drawings, U.S.A.

[12] Sugimoto, K., Nagahara, K., Kashiwase, T., Ichikawa, K., Eto, H. and Kawabata, T. (2004) Performance Evaluation Method for Reinforced Concrete Buildings. Proceedings of 13th WCEE, Vancouver, Canada, 1-6 August 2004.

[13] Personal Communication with Al Esh Office for General Contracting and Repairing of Structures. 